\title{
Effects of varied nitrate and phosphate supply on polysaccharidic and proteinaceous gel particle production during tropical phytoplankton bloom experiments
}

\author{
A. Engel, C. Borchard, A. Loginova, J. Meyer, H. Hauss, and R. Kiko \\ GEOMAR Helmholtz Centre for Ocean Research, 24105 Kiel, Germany \\ Correspondence to: A. Engel (aengel@geomar.de) \\ Received: 9 April 2015 - Published in Biogeosciences Discuss.: 30 April 2015 \\ Revised: 11 August 2015 - Accepted: 10 September 2015 - Published: 7 October 2015
}

\begin{abstract}
Gel particles such as the polysaccharidic transparent exopolymer particles (TEP) and the proteinaceous Coomassie stainable particles (CSP) play an important role in marine biogeochemical and ecological processes like particle aggregation and export, or microbial nutrition and growth. So far, effects of nutrient availability or of changes in nutrient ratios on gel particle production and fate are not well understood. The tropical ocean includes large oxygen minimum zones, where nitrogen losses due to anaerobic microbial activity result in a lower supply of nitrate relative to phosphate to the euphotic zone. Here, we report of two series of mesocosm experiments that were conducted with natural plankton communities collected from the eastern tropical North Atlantic (ETNA) close to Cape Verde in October 2012. The experiments were performed to investigate how different phosphate (experiment 1, Varied P: $0.15-1.58 \mu \mathrm{mol} \mathrm{L}^{-1}$ ) or nitrate (experiment 2, Varied $N$ : $1.9-21.9 \mu \mathrm{mol} \mathrm{L}^{-1}$ ) concentrations affect the abundance and size distribution of TEP and CSP. In the days until the bloom peak was reached, a positive correlation between gel particle abundance and Chl $a$ concentration was determined, linking the release of dissolved gel precursors and the subsequent formation of gel particles to autotrophic production. After the bloom peak, gel particle abundance remained stable or even increased, implying a continued partitioning of dissolved into particulate organic matter after biomass production itself ceased. During both experiments, differences between TEP and CSP dynamics were observed; TEP were generally more abundant than CSP. Changes in size distribution indicated aggregation of TEP after the bloom, while newly formed CSP decomposed. Abundance of gel particles clearly increased with nitrate concentration during the second experiment, suggesting
\end{abstract}

that changes in [DIN] : [DIP] ratios can affect gel particle formation with potential consequences for carbon and nitrogen cycling as well as food web dynamics in tropical ecosystems.

\section{Introduction}

Ecosystem productivity in the surface ocean is largely controlled by the availability of inorganic nutrients. The Redfield ratio describes a constant molar ratio of $\mathrm{C}: \mathrm{N}: \mathrm{P}$ of $106: 16$ : 1 and associates the relative elemental composition of seawater to that of marine organisms (Redfield, 1958; Redfield et al., 1963). It provides a widely used basis for the calculation of elemental fluxes in marine food webs and biogeochemical cycles (Sarmiento and Gruber, 2006; Sterner and Elser, 2002). On a regional or temporal scale, however, strong deviations of cellular composition from the Redfield ratio were reported (Fraga, 2001; Geider and LaRoche, 2002) and related to the physiological state of cells (Rhee, 1978; Goldman et al., 1979; Falkowski, 2000; Borchard et al., 2011; Franz et al., 2012a), differences in growth strategies (Klausmeier et al., 2004; Mills and Arrigo, 2010; Franz et al., 2012b) and changes in community structure (Sommer et al., 2004; Hauss et al., 2012). With regard to $\mathrm{CO}_{2}$ uptake and organic matter production, variations in element stoichiometry of cells have been linked to carbon overconsumption - a particular increase in carbon assimilation relative to the uptake of nitrogen and phosphorus (Toggweiler, 1993; Schartau et al., 2007), when photosynthesis proceeds, while cell division and growth are hampered due to nutrient limitation (Wood and van Valen, 1990). 
A fraction of this "excess carbon" is released from phytoplankton cells in the form of dissolved organic carbon (DOC). DOC release occurs during all stages of phytoplankton growth (Fogg, 1983; Mague et al., 1980; Bjørnsen, 1988). In natural communities, the percentage of extracellular release typically ranges between 10 and $20 \%$ (Baines and Pace, 1991; Nagata, 2000). Depending on their nutrient status, however, marine phytoplankton cells can release up to $80 \%$ of primary production as DOC (Sharp, 1977; Mague, 1980; Fogg, 1983; Bjørnsen, 1988). Thereby, the extent and composition of freshly produced DOC is affected by various environmental factors, such as temperature, $\mathrm{CO}_{2}$ concentrations and nutrient supply (Thornton, 2009; Engel et al., 2011; Borchard and Engel, 2012). Abiotic factors influencing DOC production concomitantly define its fate in the global carbon cycle. DOC can either be transferred back to $\mathrm{CO}_{2}$ by microbial degradation and respiration (Azam, 1983; Ducklow et al., 1986; del Giorgio and Duarte, 2002) or be transformed into particulate organic carbon (POC), either through uptake by organisms or by abiotic assembly and coagulation into gel particles (Alldredge et al., 1993; Chin et al., 1998; Engel et al., 2004a; Verdugo et al., 2004).

The formation of gel particles thus represents an abiotic pathway of repartitioning dissolved organic matter (DOM) into particulate organic matter (POM). To date, mostly two types of gel particles have been described in seawater: transparent exopolymer particles (TEP), which are rich in carbon and mainly originate from dissolved polysaccharides, and Coomassie stainable particles (CSP) that are rich in nitrogen and assumed to form from proteinaceous compounds (Alldredge et al., 1993; Long and Azam, 1996; Engel, 2009; Cisternas-Novoa et al., 2015). Ubiquitous in the ocean, numerical abundances of TEP and CSP around $10^{6} \mathrm{~L}^{-1}$ have been reported, with higher abundances $\left(10^{8} \mathrm{~L}^{-1}\right)$ during phytoplankton blooms (Long and Azam, 1996; Passow, 2002; Galgani et al., 2014). It has been shown that the rate of TEP formation during phytoplankton blooms is controlled by the release rate of dissolved polysaccharides (Engel et al., 2004a). TEP abundance often increases at times when phytoplankton growth becomes nutrient limited, either by nitrogen (Corzo et al., 2000; Pedrotti et al., 2010) or by phosphorus (Borchard and Engel, 2012). In addition to phytoplankton, often considered the main source of dissolved gel precursors, bacteria can significantly contribute to the DOM pool and thus to TEP and CSP formation (Radic et al., 2006; Vadstein et al., 2012). TEP play an important role in the formation of particle aggregates and therefore can enhance carbon export fluxes in marine systems (Passow et al., 2001; Engel et al., 2014). Due to the high carbohydrate content, high abundance of TEP can increase $\mathrm{C}: \mathrm{N}$ ratios of suspended and sinking particles in the ocean (Engel et al., 2002, Schneider et al., 2004; Schartau et al., 2007).

It has been suggested that CSP and TEP are different particles, as their spatial and temporal occurrence in the ocean can be quite different (Cisternas-Novoa et al., 2015). Com- pared to TEP, much less is known for processes controlling CSP formation. However, it can be assumed that dissolved precursor concentration and quality are affecting CSP formation in a similar way that DOC precursors are affecting TEP formation (Cisternas-Novoa et al., 2014). Thus, CSP formation may be part of the extracellular cycling of organic nitrogen - i.e. CSP precursors are released by microorganisms into the dissolved organic nitrogen (DON) pool and repartitioned into particles by abiotic gel particle formation. Nitrogen is often considered to be a temporarily limiting element of biomass production in marine ecosystems, favoring autoand hetero-trophic nitrogen fixation (Sarmiento and Gruber, 2006; Deutsch et al., 2007). A labile, extracellular fraction of organic nitrogen in the form of CSP thus represents a potentially important source of nutrition. Moreover, extracellular particulate nitrogen included in CSP may erroneously be attributed to the cellular nitrogen pool and may hence disguise the real nitrogen cell quota. Thus, a better knowledge of CSP formation and of the factors controlling CSP abundance may greatly improve our understanding of nitrogen cycling in marine ecosystems. So far it is unknown how much CSP contribute to variable stoichiometry of POM, but we can expect that changes in $\mathrm{N}: \mathrm{P}$ nutrient stoichiometry favoring organic nitrogen release also support higher CSP abundance, potentially increasing the nitrogen fraction in POM.

In this study, we investigated how gel particle formation is affected by different nitrate and phosphate concentrations during mesocosm bloom experiments with natural plankton communities collected from surface waters of the eastern tropical North Atlantic (ETNA), close to Cape Verde. At this site, surface waters are often depleted in nutrients (Hauss et al., 2013). Coastal upwelling, $\mathrm{N}_{2}$ fixation or deposition of aeolian dust represent prevalent pathways of nutrient, particularly inorganic nitrogen, supply to nutrient-depleted surface waters (Baker et al., 2007; Hansell et al., 2004; Hauss et al., 2013). On the other hand, anoxic mesoscale eddies have been described recently in surface waters around Cape Verde, potentially leading to enhanced nitrogen losses (Karstensen et al., 2015). Thus, pelagic communities in the euphotic zone of the ETNA are occasionally exposed to nutrient pulses with different $\left[\mathrm{NO}_{3}^{-}\right]$: $\left[\mathrm{PO}_{4}^{3-}\right]$ ratios in surface waters.

Understanding the impact of changes in nutrient stoichiometry on phytoplankton communities in the tropical ocean may also help to better estimate consequences of suboxia on ecosystem productivity and biogeochemical cycling. Coastal boundary upwelling systems in the ETNA and eastern tropical North Pacific (ETNP) include some of the largest oxygen minimum zones (OMZs) in the ocean $(<20$ $45 \mu \mathrm{mol} \mathrm{O} \mathrm{kg}^{-1}$; Gilly et al., 2013). Although they comprise only a small fraction of the global ocean by volume, they nevertheless play a pivotal role in controlling the oceans nutrient regimes (Lam and Kuypers, 2011). A profound loss of the oceanic nitrate stock was suggested to occur in OMZs (Sarmiento and Gruber, 2006; Codispoti et al., 2001) due to microbial processes, such as heterotrophic denitrification and 
anaerobic ammonium oxidation (anammox; Codispoti and Richards, 1976; Kuypers et al., 2005). As a consequence, the $\left[\mathrm{NO}_{3}^{-}\right]:\left[\mathrm{PO}_{4}^{3-}\right]$ stoichiometry of upwelling water masses above OMZs with strong nitrogen loss often deviates from the canonical Redfield ratio of 16 (Deutsch et al., 2007). Because global climate change may lead to an expansion of OMZs, particularly in the Atlantic and Pacific Ocean (Stramma et al., 2008), future changes in surface ocean nutrient cycling are to be expected.

Our experiments aimed to identify effects of varied nutrient supply and stoichiometry on the abundance and size distribution of TEP and CSP, their dissolved precursors, and the potential impact on carbon and nitrogen cycling.

\section{Methods}

\subsection{Setup of the mesocosms}

Two 8-day mesocosm experiments were conducted in October 2012 at the Instituto Nacional de Desenvolvimento das Pescas (INDP), Mindelo, Cape Verde. Surface water was collected with RV Islandia south of São Vicente $\left(16^{\circ} 44.4^{\prime} \mathrm{N}\right.$, $25^{\circ} 09.4^{\prime} \mathrm{W}$ ) using four $600 \mathrm{~L}$ containers. Surface water was collected during the night of 1 and 2 October 2012 (first experiment) and 11 and 12 October 2012 (second experiment). Sixteen mesocosm (MK) bags were placed in four flow-through water baths and shaded with blue, transparent lids to approximately $20 \%$ of surface irradiation. Mesocosm bags were filled from the containers by gravity, using a submerged hose to minimize bubbles. A mesh to filter out zooplankton was not used in order to avoid changes in the community composition as well as breakage of delicate cells. The accurate volume inside the individual bags was calculated after addition of $1.5 \mathrm{mmol}$ silicate and measuring the resulting silicate concentration. The volume ranged from 106 to $145 \mathrm{~L}$. In order to keep the temperature constant, all mesocosms were evenly distributed between four water baths, the temperature of which was maintained at $25.9-28.7^{\circ} \mathrm{C}$ using water from the bay close to the experiment site. Daily sampling was conducted between 09:00 and 10:30 LT with a 10 L beaker completely rinsed with ultrapure water. Between 5.5 and $7 \mathrm{~L}$ was sampled from each mesocosm at the surface and used for all further analyses. The mesocosms were gently mixed prior to sampling to obtain representative samples for the entire mesocosm.

The experimental manipulation comprised additions of different amounts of nitrate $\left(\mathrm{NO}_{3}^{-}\right)$and phosphate $\left(\mathrm{PO}_{4}^{3-}\right)$ at day 1 of the experiment. Treatment identifications specifying micromolar target concentrations of $\mathrm{NO}_{3}^{-}$and $\mathrm{PO}_{4}^{3-}$ are given in Table 1 . Nutrient concentrations before nutrient addition were below the detection limit for $\mathrm{NO}_{3}^{-}, \mathrm{NO}_{2}^{-}$and $\mathrm{PO}_{4}^{3-}$, while only traces of $\mathrm{NH}_{4}^{+}\left(<0.08 \mu \mathrm{mol} \mathrm{L}^{-1}\right)$ were determined.
In experiment 1 (referred to as Varied $P$ in the following), the $\mathrm{PO}_{4}^{3-}$ supply was changed at constant $\mathrm{NO}_{3}^{-}$supply, yielding a range of $0.25-1.75 \mu \mathrm{mol} \mathrm{L}-1 \mathrm{PO}_{4}^{3-}$ at $12.0 \mu \mathrm{mol} \mathrm{L}-1$ $\mathrm{NO}_{3}^{-}$(Table 1) for 13 tanks. Two additional mesocosms were set to $1.10 \mu \mathrm{mol} \mathrm{L}-1 \mathrm{PO}_{3}^{4-}$ at 6.35 and $17.65 \mu \mathrm{mol} \mathrm{L}{ }^{-1} \mathrm{NO}_{3}^{-}$, respectively, representing low- and high- $\mathrm{NO}_{3}^{-}$treatments. One mesocosm (MK 5) received erroneous filling during the Varied $P$ experiment and was excluded from data evaluation. Realized concentrations of $\mathrm{PO}_{3}^{4-}$ and $\mathrm{NO}_{3}^{-}$inside the mesocosms slightly deviated from target values (Table 1), which may be due to fast uptake or underestimation of water volume. Initial $\left[\mathrm{NO}_{3}^{-}\right]:\left[\mathrm{PO}_{4}^{3-}\right]^{-}$during Varied $P$ covered a range of $6.7-77$, with ratios similar to, or smaller than, the Redfield value in 11 out of 15 mesocosms, suggesting nonP-limiting conditions in the majority of mesocosms during the first experiment.

During experiment 2 (referred to as Varied $N$ in the following), initial $\mathrm{NO}_{3}^{-}$concentration was varied at relatively constant $\mathrm{PO}_{3}^{4-}$ concentration, yielding a target range of 2.0$20.0 \mu \mathrm{mol} \mathrm{L}{ }^{-1} \mathrm{NO}_{3}^{-}$at $0.75 \mu \mathrm{mol} \mathrm{L}{ }^{-1} \mathrm{PO}_{4}^{3-}$ in 12 out of 16 MKs (Table 1). In addition, two low- and two high- $\mathrm{PO}_{3}^{4-}$ treatments at low and high $\mathrm{NO}_{3}^{-}$were realized. The realized nutrient concentrations deviated only slightly from target values. $\left[\mathrm{NO}_{3}^{-}\right]:\left[\mathrm{PO}_{4}^{3-}\right]$ during Varied $N$ thus covered a range of 3.3-84 with ratios of $>16$, in 9 out of 16 mesocosms, suggesting non-N-limiting conditions in the majority of mesocosms during the second experiment. Two nutrient treatments were realized in both experiments: $12.0 \mathrm{~N} / 0.75 \mathrm{P}$ with four replicates during Varied $P$ and three replicates during Varied $N$, and $6.35 \mathrm{~N} / 1.10 \mathrm{P}$ with one mesocosm during each experiment.

\subsection{Analytical methods}

\subsubsection{Inorganic nutrient}

The dissolved inorganic nutrients nitrate $\left(\mathrm{NO}_{3}^{-}\right)$, nitrite $\left(\mathrm{NO}_{2}^{-}\right)$and phosphate $\left(\mathrm{PO}_{4}^{3-}\right)$ were determined from $10 \mathrm{~mL}$ samples.

Duplicate measurements were carried out within $4 \mathrm{~h}$ after sampling using a Quattro autoanalyzer according to Hansen and Koroleff (2007). Detection limits of nutrients were $0.01 \mu \mathrm{mol} \mathrm{L}^{-1}$ for $\mathrm{NO}_{2}^{-}$and $\mathrm{PO}_{4}^{3-}$ and $0.03 \mu \mathrm{mol} \mathrm{L}-1$ for $\mathrm{NO}_{3}^{-}$.

\subsubsection{Gel particles}

For TEP and CSP, duplicate samples of $20-80 \mathrm{~mL}$ were gently (<150 mbar) filtered onto $25 \mathrm{~mm}$ Nuclepore membrane filters $(0.4 \mu \mathrm{m}$ pore size, Whatman Ltd.). Samples were stained with either $1 \mathrm{~mL}$ of pre-filtered $(<0.2 \mu \mathrm{m}) \mathrm{Al}-$ cian Blue solution (Allredge et al., 1993) or $1 \mathrm{~mL}$ of prefiltered $(<0.2 \mu \mathrm{m})$ Coomassie Brilliant Blue solution (Long and Azam, 1996). After a staining time of approximately 
Table 1. Summary of initial conditions of the seawater used to fill the mesocosms during the two experiments, target nutrient concentrations (Treat-ID), and different nutrient conditions inside the mesocosms after nutrient addition (day 1).

\begin{tabular}{|c|c|c|c|c|c|c|c|c|c|}
\hline & \multicolumn{4}{|c|}{ Varied $P$} & & \multicolumn{4}{|c|}{ Varied $N$} \\
\hline \multicolumn{10}{|l|}{ Day 0} \\
\hline Latitude & \multicolumn{4}{|c|}{$16.74^{\circ} \mathrm{N}$} & & \multicolumn{4}{|c|}{$16.76^{\circ} \mathrm{N}$} \\
\hline Longitude & \multicolumn{4}{|c|}{$25.16^{\circ} \mathrm{W}$} & & \multicolumn{4}{|c|}{$25.16^{\circ} \mathrm{W}$} \\
\hline $\mathrm{POC}\left[\mu \mathrm{mol} \mathrm{L}^{-1}\right]$ & \multicolumn{4}{|c|}{$13.6 \pm 3.8$} & & \multicolumn{4}{|c|}{$11.9 \pm 1.9$} \\
\hline $\mathrm{PON}\left[\mu \mathrm{mol} \mathrm{L}^{-1}\right]$ & \multicolumn{4}{|c|}{$1.85 \pm 0.68$} & & \multicolumn{4}{|c|}{$1.54 \pm 0.26$} \\
\hline $\mathrm{POP}\left[\mu \mathrm{mol} \mathrm{L}^{-1}\right]$ & \multicolumn{4}{|c|}{$0.10 \pm 0.02$} & & \multicolumn{4}{|c|}{$0.07 \pm 0.01$} \\
\hline Chl $a\left[\mu \mathrm{g} \mathrm{L}^{-1}\right]$ & \multicolumn{4}{|c|}{$0.38 \pm 0.09$} & & \multicolumn{4}{|c|}{$0.18 \pm 0.05$} \\
\hline $\mathrm{DOC}\left[\mu \mathrm{mol} \mathrm{L}{ }^{-1}\right]$ & \multicolumn{4}{|c|}{$95 \pm 4.6$} & & \multicolumn{4}{|c|}{$96 \pm 3.9$} \\
\hline $\mathrm{DON}\left[\mu \mathrm{mol} \mathrm{L}^{-1}\right]$ & \multicolumn{4}{|c|}{$8.8 \pm 1.1$} & & \multicolumn{4}{|c|}{$11 \pm 1.5$} \\
\hline \multicolumn{10}{|l|}{ Day 1} \\
\hline Mesocosm & $\begin{array}{r}\text { Nitrate } \\
{\left[\mu \mathrm{mol} \mathrm{L}^{-1}\right]}\end{array}$ & $\begin{array}{r}\text { Phosphate } \\
{\left[\mu \mathrm{mol} \mathrm{L}^{-1}\right]}\end{array}$ & DIN : DIP & Treat-ID & Mesocosm & $\begin{array}{r}\text { Nitrate } \\
{\left[\mu \mathrm{mol} \mathrm{L}^{-1}\right]}\end{array}$ & $\begin{array}{r}\text { Phosphate } \\
{\left[\mu \mathrm{mol} \mathrm{L}{ }^{-1}\right]}\end{array}$ & DIN : DIP & Treat-ID \\
\hline MK 13 & 11.2 & 0.15 & 76.8 & $12.0 \mathrm{~N} / 0.25 \mathrm{P}$ & MK 13 & 2.1 & 0.46 & 4.5 & $2.0 \mathrm{~N} / 0.75 \mathrm{P}$ \\
\hline MK 14 & 11.2 & 0.16 & 69.8 & $12.0 \mathrm{~N} / 0.25 \mathrm{P}$ & MK 15 & 1.9 & 0.56 & 3.3 & $2.0 \mathrm{~N} / 0.75 \mathrm{P}$ \\
\hline MK 16 & 11.3 & 0.15 & 75.8 & $12.0 \mathrm{~N} / 0.25 \mathrm{P}$ & MK 16 & 2.7 & 0.48 & 5.6 & $2.0 \mathrm{~N} / 0.75 \mathrm{P}$ \\
\hline MK 1 & 11.5 & 0.73 & 15.8 & $12.0 \mathrm{~N} / 0.75 \mathrm{P}$ & MK 9 & 4.6 & 0.45 & 10.4 & $4.0 \mathrm{~N} / 0.75 \mathrm{P}$ \\
\hline MK 2 & 11.0 & 0.68 & 16.1 & $12.0 \mathrm{~N} / 0.75 \mathrm{P}$ & MK 11 & 4.5 & 0.47 & 9.6 & $4.0 \mathrm{~N} / 0.75 \mathrm{P}$ \\
\hline MK 3 & 10.6 & 0.52 & 20.5 & $12.0 \mathrm{~N} / 0.75 \mathrm{P}$ & MK 12 & 4.0 & 0.49 & 8.2 & $4.0 \mathrm{~N} / 0.75 \mathrm{P}$ \\
\hline MK 10 & 10.8 & 0.61 & 17.6 & $12.0 \mathrm{~N} / 0.75 \mathrm{P}$ & MK 14 & 12.6 & 0.47 & 27.0 & $12.0 \mathrm{~N} / 0.75 \mathrm{P}$ \\
\hline MK 6 & 10.7 & 1.14 & 9.4 & $12.0 \mathrm{~N} / 1.25 \mathrm{P}$ & MK 4 & 12.4 & 0.51 & 24.3 & $12.0 \mathrm{~N} / 0.75 \mathrm{P}$ \\
\hline MK 7 & 11.2 & 1.12 & 9.9 & $12.0 \mathrm{~N} / 1.25 \mathrm{P}$ & MK 1 & 12.6 & 0.51 & 24.7 & $12.0 \mathrm{~N} / 0.75 \mathrm{P}$ \\
\hline MK 8 & 10.9 & 1.09 & 10.0 & $12.0 \mathrm{~N} / 1.25 \mathrm{P}$ & MK 2 & 20.6 & 0.47 & 43.9 & $20.0 \mathrm{~N} / 0.75 \mathrm{P}$ \\
\hline MK 9 & 10.5 & 1.57 & 6.7 & $12.0 \mathrm{~N} / 1.75 \mathrm{P}$ & MK 3 & 20.6 & 0.45 & 45.9 & $20.0 \mathrm{~N} / 0.75 \mathrm{P}$ \\
\hline MK 11 & 10.8 & 1.58 & 6.9 & $12.0 \mathrm{~N} / 1.75 \mathrm{P}$ & MK 6 & 21.9 & 0.45 & 48.8 & $20.0 \mathrm{~N} / 0.75 \mathrm{P}$ \\
\hline MK 12 & 11.1 & 1.53 & 7.2 & $12.0 \mathrm{~N} / 1.75 \mathrm{P}$ & MK 7 & 6.7 & 0.78 & 8.5 & $6.0 \mathrm{~N} / 1.03 \mathrm{P}$ \\
\hline MK 4 & 5.7 & 1.00 & 5.7 & $6.35 \mathrm{~N} / 1.10 \mathrm{P}$ & MK 8 & 6.9 & 0.18 & 39.4 & $6.35 \mathrm{~N} / 0.40 \mathrm{P}$ \\
\hline \multirow[t]{2}{*}{ MK 15} & 16.9 & 1.01 & 16.7 & $17.65 \mathrm{~N} / 1.10 \mathrm{P}$ & MK 10 & 18.5 & 0.22 & 84.3 & $17.65 \mathrm{~N} / 0.40 \mathrm{P}$ \\
\hline & & & & & MK 5 & 18.4 & 0.79 & 23.4 & $17.65 \mathrm{~N} / 1.10 \mathrm{P}$ \\
\hline \multirow[t]{8}{*}{ Legends } & $\star$ & \multicolumn{3}{|c|}{$12.0 \mathrm{~N} / 0.25 \mathrm{P}$} & $x$ & \multicolumn{4}{|c|}{$2.00 \mathrm{~N} / 0.75 \mathrm{P}$} \\
\hline & $\bullet$ & \multicolumn{3}{|c|}{$12.0 \mathrm{~N} / 0.75 \mathrm{P}$} & $\circ$ & \multicolumn{4}{|c|}{$4.00 \mathrm{~N} / 0.75 \mathrm{P}$} \\
\hline & $\nabla$ & & $5.35 \mathrm{~N} / 1$. & & $\nabla$ & & $6.00 \mathrm{~N} / 1.10 \mathrm{P}$ & & \\
\hline & च & & $17.65 \mathrm{~N} / 1$. & & $\bullet$ & & $6.35 \mathrm{~N} / 0.40 \mathrm{P}$ & & \\
\hline & $x$ & & $12.0 \mathrm{~N} / 1.2$ & & $\bullet$ & & $12.0 \mathrm{~N} / 0.75 \mathrm{P}$ & & \\
\hline & $\Delta$ & & $12.0 \mathrm{~N} / 1.7$ & & * & & $17.65 \mathrm{~N} / 0.40 \mathrm{P}$ & & \\
\hline & & & & & 口 & & $17.65 \mathrm{~N} / 1.10 \mathrm{P}$ & & \\
\hline & & & & & $\varnothing$ & & $20.0 \mathrm{~N} / 0.75 \mathrm{P}$ & & \\
\hline
\end{tabular}

4 (Alcian Blue) or $30 \mathrm{~s}$ (Coomassie Brilliant Blue), the excessive dye was removed by rinsing the filter with several milliliters of Milli-Q water. Blank filters were prepared from the same Milli-Q water. No samples for gel particles were taken during Varied $P$ on day 3 and 4 due to a breakdown of the ultrapure water system.

Each filter was placed on the white side of a semitransparent glass slide (CytoClear, Poretics Corp., Livermore, US) and stored frozen $\left(-20^{\circ} \mathrm{C}\right)$ until microscopic analysis. Abundance, area and size-frequency distribution of TEP and CSP in the size range $1-760 \mu \mathrm{m}$ were determined following Engel (2009) using a light microscope (Zeiss Axio Scope A.1) connected to a camera (AxioCAM Mrc). Filters were screened at $200 \times$ magnification. Thirty pictures were taken randomly from each filter in two perpendicular cross sections (15 pictures each; resolution $1040 \times 1040$ pixel, 8 bit color depth). WCIF ImageJ image analysis software (version 1.44, public domain, developed at the US National
Institutes of Health, courtesy of Wayne Rasband, National Institute of Mental Health, Bethesda, Maryland) was used to semi-automatically analyze particle numbers and area.

The size-frequency distribution of gel particles can be described by

$$
\frac{\mathrm{d} N}{\mathrm{~d}\left(d_{\mathrm{p}}\right)}=k d_{\mathrm{p}}^{\delta}
$$

where $\mathrm{d} N$ is the number of particles per unit water volume in the size range $d_{\mathrm{p}}$ to $\left[d_{\mathrm{p}}+\mathrm{d}\left(d_{\mathrm{p}}\right)\right]$, with $d_{\mathrm{p}}$ being the equivalent spherical diameter (ESD); $k$ is a constant that depends on the total number of particles per volume; and $\delta(\delta<0)$ describes the spectral slope of the size distribution. The less negative $\delta$ is, the greater the fraction of larger gels. Both $\delta$ and $k$ were derived from regressions of $\log \left[\mathrm{d} N / \mathrm{d}\left(d_{\mathrm{p}}\right)\right]$ versus $\log \left[d_{\mathrm{p}}\right]$ (Mari and Kiørboe, 1996). The value $\delta$ is related to the slope of the cumulative size distribution $N=a d_{\mathrm{p}}^{\beta}$ by 
$\delta=\beta+1$. To determine $\delta$, data for CSP and TEP were fitted over the size range 1.05-14.14 $\mu \mathrm{m}$ ESD. Median sizes (ESD) of TEP and CSP were determined over the whole size range $(1-760 \mu \mathrm{m})$.

The carbon content of TEP (TEP-C) was estimated following Mari (1999) using the size-dependent relationship

TEP-C $=a \Sigma_{\mathrm{i}} n_{\mathrm{i}} r_{\mathrm{i}}^{D}$,

with $n_{\mathrm{i}}$ being the number of TEP in the size class $i$ and $r_{\mathrm{i}}$ the mean equivalent spherical radius of the size class. The constant $a=0.25 \times 10^{-6}(\mu \mathrm{g} \mathrm{C})$ and the fractal dimension of aggregates $D=2.55$ were proposed by Mari (1999). In order to relate TEP-C to POC and TOC, data are given as $\mu \mathrm{mol} \mathrm{L} \mathrm{L}^{-1}$.

\subsubsection{Dissolved organic carbon and nitrogen}

Duplicate samples for DOC $(20 \mathrm{~mL})$ were filtered through pre-combusted $\mathrm{GF} / \mathrm{F}$ filters $\left(450^{\circ} \mathrm{C}\right.$ for $\left.5 \mathrm{~h}\right)$ and collected in pre-combusted glass ampoules $\left(450^{\circ} \mathrm{C}\right.$ for $\left.5 \mathrm{~h}\right)$. Samples were acidified with $80 \mu \mathrm{L}$ of $85 \%$ phosphoric acid, flamesealed and stored at $4{ }^{\circ} \mathrm{C}$ in the dark until analysis. DOC samples were analyzed by applying the high-temperature catalytic oxidation method (TOC-VCSH, Shimadzu) following Sugimura and Suzuki (1988). The instrument was calibrated every $8-10$ days by measuring standard solutions of 0,500 , $1000,1500,2500$ and $5000 \mu \mathrm{g} \mathrm{C} \mathrm{L}{ }^{-1}$, prepared from a potassium hydrogen phthalate standard (Merck 109017). Every measurement day, ultrapure (Milli-Q) water was used for setting the instrument baseline, followed by the measurement of deep-sea water with known DOC concentration (Dennis Hansell, RSMAS, University of Miami) to verify results. Additionally, two internal standards with DOC within the range of found in samples were prepared each measurement day using a potassium hydrogen phthalate (Merck 109017). DOC concentration was determined in each sample from five to eight injections.

Simultaneously with DOC, total dissolved nitrogen (TDN) was determined using the TNM-1 detector on the Shimadzu analyzer. Dissolved organic nitrogen (DON) was calculated from TDN by subtraction of $\mathrm{NO}_{3}^{-}$and $\mathrm{NO}_{2}^{-}$concentrations.

\subsubsection{Chlorophyll $a$}

Samples $(0.5-1 \mathrm{~L})$ of chlorophyll $a(\mathrm{Chl} a)$ were vacuumfiltered (<200 mbar) onto Whatman GF/F filters $(25 \mathrm{~mm})$, $1 \mathrm{~mL}$ of ultrapure water was added and the filters were frozen at $-20^{\circ} \mathrm{C}$ for at least $24 \mathrm{~h}$. Subsequently, $9 \mathrm{~mL}$ of acetone $(100 \%)$ was added to each sample and the fluorescence was measured with a Turner Trilogy fluorometer, which was calibrated with a Chl $a$ standard (Anacystis nidulans, Walter CMP) dilution series. Chl $a$ concentrations were calculated according to Parsons et al. (1984).

\subsubsection{Bacterial abundance}

Bacterial cell counts were obtained by flow cytometry (FACSCalibur, Becton Dickinson, San Jose, CA, USA). Samples $(5 \mathrm{~mL})$ were fixed with formaldehyde $(2 \%$ final concentration), frozen at $-80^{\circ} \mathrm{C}$ and transported to the home laboratory. Samples were diluted $1: 3$, stained with SYBR Green I (Molecular Probes) and measured at a flow rate of 11.0 $\mu \mathrm{L} \mathrm{min}^{-1}$.

\subsubsection{Particulate organic carbon and nitrogen}

For analyses of particulate organic carbon (POC) and particulate nitrogen $(\mathrm{PN})$ water samples $(0.5-1 \mathrm{~L})$ were filtered onto pre-combusted $\left(450^{\circ} \mathrm{C}\right.$ for $\left.5 \mathrm{~h}\right)$ Whatman $\mathrm{GF} / \mathrm{F}$ filters $(25 \mathrm{~mm}, 0.7 \mu \mathrm{m})$ under low pressure $(<200 \mathrm{mbar})$. Filters were frozen at $-20^{\circ} \mathrm{C}$ and stored until analysis. Prior to analysis, filters were acid-fumed $(37 \% \mathrm{HCl}$ for $24 \mathrm{~h}$ ) in order to remove inorganic carbon and dried at $40^{\circ} \mathrm{C}$ for $24 \mathrm{~h}$. Subsequently, filters were wrapped in tin cups $(8 \times 8 \times 15 \mathrm{~mm})$, combusted and analyzed according to Sharp (1974) using an elemental analyzer (Euro EA).

\subsection{Data analysis}

Differences in terms of nutrient manipulation and course of the experiments were statistically tested by multiple comparison (Holm-Šidák method) or by two-way ANOVA, with factors being the treatment identification (Table 1) and day of the experiment, respectively. To determine a potential effect of the nutrient treatment, the mean deviation (MD) of a component in a mesocosm was calculated as the mean of daily deviations. Deviations were calculated for each sampling day by subtracting the mean value of all mesocosms at that day from the value of the individual mesocosm of the same day. For each experiment, MD values were correlated to the initial (day 1) nutrient concentration. The overall significance level was $p<0.05$. Statistical tests were performed using SigmaPlot 12.0 (Systat).

\section{Results}

\subsection{Phytoplankton bloom and nutrient development}

The development of phytoplankton blooms during the mesocosm experiments and the build-up of particulate matter are described in more detail in Meyer et al. (2015) and are summarized here only briefly.

Before nutrient addition (day 0), Chl $a$ concentration was on average $0.38 \pm 0.09 \mu \mathrm{g} \mathrm{L}^{-1}$ in all mesocosms of Varied $P$ and hence higher than at the start of Varied $N$ with $0.18 \pm 0.05 \mu \mathrm{g} \mathrm{L}^{-1}$ (Table 1). As long as nutrients were replete, bloom development was similar in all mesocosms within each experiment (Fig. 1a-f). However, during Varied $P$ most mesocosms reached maximum $\mathrm{Chl} a$ concentrations, 

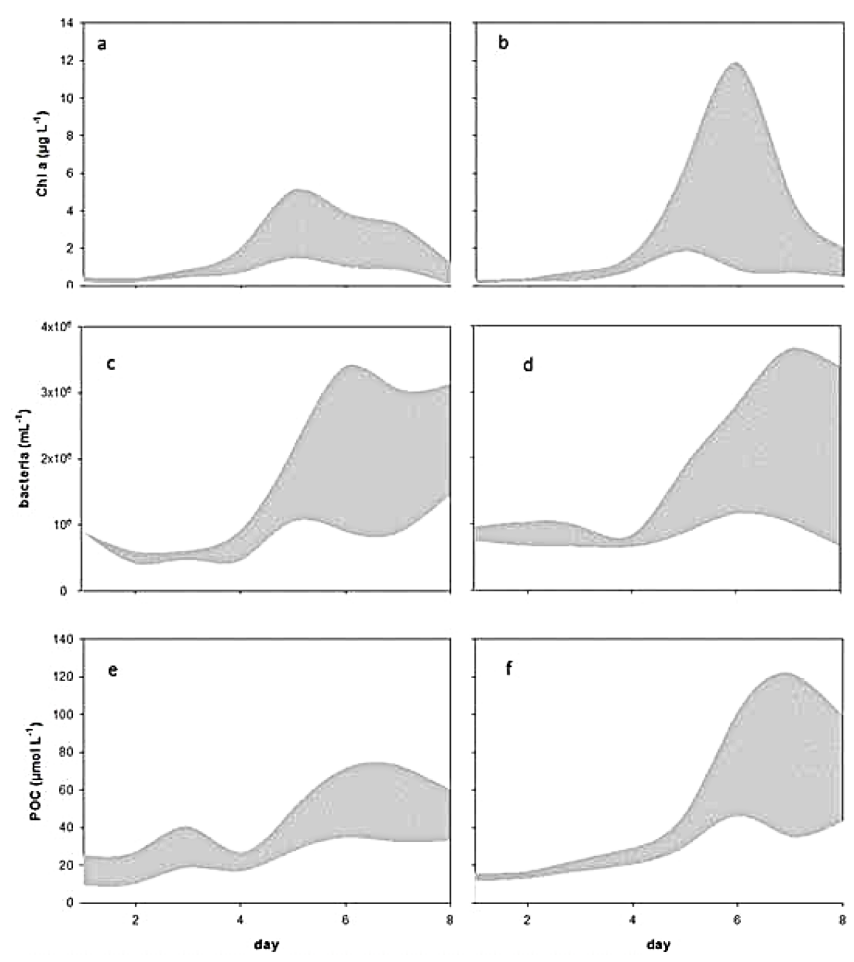

Figure 1. Bloom development during two series of mesocosm experiments, one with varied supply of $\mathrm{PO}_{4}^{3-}$ (Varied $\mathrm{P} ; \mathbf{a}, \mathbf{c}, \mathbf{e}$; $n=16$ ) and one with $\mathrm{NO}_{3}^{-}$(Varied $N ; \mathbf{b}, \mathbf{d}, \mathbf{f} ; n=16$ ). Shaded areas indicate the range (min-max) of data observed during both treatments for $\mathrm{Chl} a$ concentration (a, b), bacterial abundance (c, d) and particulate organic carbon (POC) concentration $(\mathbf{e}, \mathbf{f})$.

i.e. bloom peak, on day 5 and thus 1 day earlier than during Varied $N$ (Fig. 1a, b). Maximum Chl $a$ concentration ranged between 2.1 and $3.3 \mu \mathrm{g} \mathrm{L}^{-1}$ during Varied $P$ and between 2 and $10 \mu \mathrm{gL}^{-1}$ during Varied $N$. Hence, during Varied $N$ higher concentrations of $\mathrm{Chl} a$ were determined as well as a higher variability among mesocosms. During both experiments, MDs of Chl $a$ concentration in the different mesocosms were correlated to the concentration of the initial nutrient varied, i.e. $\mathrm{PO}_{4}^{3-}$ during Varied $\mathrm{P}$ and $\mathrm{NO}_{3}^{-}$during Varied $N$, although the response was much stronger during Varied $N$ (Table 2). The phytoplankton biomass composition was dominated by diatoms (data not shown). Diazotrophic bacteria of the genus Trichodesmium were more present in the initial waters of Varied $P$, while proteobacterial diazotrophs were more abundant in Varied $N$ (Meyer et al., 2015).

Bacterial abundance was not determined before nutrient addition, but data from day 2 showed higher abundance in mesocosms of Varied $N$ with $8.37 \times 10^{5} \pm 9.80 \times 10^{4}$ compared to $5.26 \times 10^{5} \pm 5.48 \times 10^{4} \mathrm{~mL}^{-1}$ for Varied $P$. During the first 4 days of both experiments, cell numbers remained relatively stable or even decreased slightly (Fig. 1c, d). After day 5, cell numbers increased in all mesocosms and strongly differed between treatments. During Varied
$P$, different $\mathrm{PO}_{4}^{3-}$ addition could not significantly explain differences in bacterial abundance (Table 2). Instead, highest abundances in the bloom phase were reached in the "centerpoint" treatment $(12.0 \mathrm{~N} / 0.75 \mathrm{P})$, with a maximum value of $2.4 \times 10^{6} \pm 7.1 \times 10^{5} \mathrm{~mL}^{-1}$ on day 6 compared to $2.3 \times 10^{6} \pm 7.1 \times 10^{5}, 1.5 \times 10^{6} \pm 3.0 \times 10^{5}$ and $1.7 \times 10^{6} \pm 8.4 \times 10^{5} \mathrm{~mL}^{-1}$ in treatments $12.0 \mathrm{~N} / 0.25 \mathrm{P}$, $12.0 \mathrm{~N} / 1.25 \mathrm{P}$ and $12.0 \mathrm{~N} / 1.75 \mathrm{P}$, respectively. During Varied $N$, bacterial abundances were positively influenced by $\mathrm{NO}_{3}^{-}$input (Table 2). At the end of the experiment (day 8), $1.6 \times 10^{6} \pm 4.7 \times 10^{5}$ and $2.3 \times 10^{6} \pm 5.4 \times 10^{5} \mathrm{~mL}^{-1}$ cells were observed in the high- $\mathrm{NO}_{3}^{-}$treatments $20.0 \mathrm{~N} / 0.75 \mathrm{P}$ and $12.0 / 0.75 \mathrm{P}$, respectively, compared to $8.1 \times 10^{5} \pm 1.4 \times 10^{5}$ and $1.0 \times 10^{6} \pm 1.5 \times 10^{5} \mathrm{~mL}^{-1}$ in $2.0 \mathrm{~N} / 0.75 \mathrm{P}$ and $4.0 \mathrm{~N} / 0.75 \mathrm{P}$, respectively.

Initial concentrations of POC were $13.6 \pm 3.8$ and $11.9 \pm 1.9 \mu \mathrm{mol} \mathrm{L}^{-1}$ during Varied $P$ and Varied $N$, respectively (Table 1). During both experiments, concentrations increased steadily until day 6 and remained relatively stable thereafter (Fig. 1e, f). POC concentrations during Varied $P$ were up to $73 \mu \mathrm{mol} \mathrm{L}^{-1}(17.65 \mathrm{~N} / 1.10 \mathrm{P})$, but not related to the initial $\mathrm{PO}_{4}^{3-}$ addition. In contrast, build-up of POC was more pronounced during Varied $N$, with values up to $102 \pm 18 \mu \mathrm{mol} \mathrm{L}^{-1}$ determined in treatments with the highest initial $\mathrm{NO}_{3}^{-}$supply $(20.0 \mathrm{~N} / 0.75 \mathrm{P})$, and indicated a clear correlation to the initial $\mathrm{NO}_{3}^{-}$treatment (Table 2).

Along with plankton growth, inorganic nutrient concentrations declined (Fig. 2). During Varied $P, \mathrm{PO}_{4}^{3-}$ was exhausted on day 5 in the treatments with the lowest initial $\mathrm{PO}_{4}^{3-}$ supply and the highest initial $\left[\mathrm{NO}_{3}^{-}\right]$: $\left[\mathrm{PO}_{4}^{3-}\right]$ ratio of 74 , i.e. $12.0 \mathrm{~N} / 0.25 \mathrm{P}$. In all other treatments, $\mathrm{PO}_{4}^{3-}$ depletion was reached later during the experiment, except for the highest $\mathrm{PO}_{4}^{3-}$ treatment $(12.0 \mathrm{~N} / 1.75 \mathrm{P})$, in which $\mathrm{PO}_{4}^{3-}$ remained $>0.3 \mu \mathrm{mol} \mathrm{L}^{-1}$ until the last experimental day. During the same experiment, $\mathrm{NO}_{3}^{-}$concentrations fell below the detection limit of $0.03 \mu \mathrm{mol} \mathrm{L}{ }^{-1}$ in some of the mesocosms after day 5 but were not depleted in $12.0 \mathrm{~N} / 0.25 \mathrm{P}$. During Varied $\mathrm{N}, \mathrm{NO}_{3}^{-}$was exhausted on day 5 in the low$\mathrm{N}$-supply mesocosms (2.00N / 0.75P and 4.00N / 0.75P). On day $6, \mathrm{NO}_{3}^{-}$was still available in treatments with an initial nitrate supply $>12 \mu \mathrm{mol} \mathrm{L}^{-1}$, and on day $8 \mathrm{NO}_{3}^{-}$was only available in $17.65 \mathrm{~N} / 0.40 \mathrm{P}$, the mesocosms with the highest $\left[\mathrm{NO}_{3}^{-}\right]$: $\left[\mathrm{PO}_{4}^{3-}\right]$ ratio of 84 . After the bloom, $\mathrm{PO}_{4}^{3-}$ was below the detection limit in 9 out of 16 mesocosms with $\left[\mathrm{NO}_{3}^{-}\right]:\left[\mathrm{PO}_{4}^{3-}\right]$ ratios $>10$.

\subsection{Dissolved organic carbon (DOC) and nitrogen (DON)}

Averaged for all mesocosms, initial (day 1) DOC concentration was very similar for Varied $P\left(95 \pm 5 \mu \mathrm{mol} \mathrm{C} \mathrm{L}{ }^{-1}\right)$ and Varied $N\left(96 \pm 4 \mu \mathrm{mol} \mathrm{CL}^{-1}\right.$; Table 1$)$. Throughout both experiments, DOC concentrations increased steadily after day 2 , except for day 5 , when a slight decrease was observed 
Table 2. Mean deviations (MDs) from the average development, averaged for each mesocosm for the full experimental period (day 1-8) and Pearson coefficients for correlations of MD versus initial $\mathrm{PO}_{4}^{3-}\left(\right.$ Varied $\left.P ; \mu \mathrm{mol} \mathrm{L}{ }^{-1}\right)$ and $\mathrm{NO}_{3}^{-}\left(\right.$Varied $\left.N ; \mu \mathrm{mol} \mathrm{L}{ }^{-1}\right)$ concentrations; bold numbers indicate significant correlation $(p<0.05)$.

\begin{tabular}{|c|c|c|c|c|c|c|c|c|c|c|c|c|c|c|c|c|c|}
\hline $\begin{array}{l}\text { Varied } P \\
\text { treatment }\end{array}$ & $\begin{array}{r}\text { Chl } a \\
\mu \mathrm{g} \mathrm{L}-1\end{array}$ & $\begin{array}{r}\text { Bact. } \\
10^{5} \mathrm{~mL}^{-1}\end{array}$ & $\begin{array}{r}\text { POC } \\
\mu \mathrm{M}\end{array}$ & $\begin{array}{l}\mathrm{PN} \\
\mu \mathrm{M}\end{array}$ & $\begin{array}{r}\text { DOC } \\
\mu \mathrm{M}\end{array}$ & $\begin{array}{r}\text { DON } \\
\mu \mathrm{M}\end{array}$ & $\begin{array}{r}\text { TEP } \\
10^{6} \mathrm{~L}^{-1}\end{array}$ & $\begin{array}{r}\text { CSP } \\
10^{6} \mathrm{~L}^{-1}\end{array}$ & $\begin{array}{r}\text { Varied } N \\
\text { treatment }\end{array}$ & $\begin{array}{r}\text { Chl } a \\
\mu \mathrm{g} \mathrm{L}^{-1}\end{array}$ & $\begin{array}{r}\text { Bact. } \\
10^{5} \mathrm{~mL}^{-1}\end{array}$ & $\begin{array}{r}\text { POC } \\
\mu \mathrm{M}\end{array}$ & $\begin{array}{l}\mathrm{PN} \\
\mu \mathrm{M}\end{array}$ & $\begin{array}{r}\text { DOC } \\
\mu \mathrm{M}\end{array}$ & $\begin{array}{r}\text { DON } \\
\mu \mathrm{M}\end{array}$ & $\begin{array}{r}\text { TEP } \\
10^{6} \mathrm{~L}^{-1}\end{array}$ & $\begin{array}{r}\text { CSP } \\
10^{6} \mathrm{~L}^{-1}\end{array}$ \\
\hline $12.0 \mathrm{~N} / 0.75 \mathrm{P}$ & -0.21 & 2.84 & 2.45 & 0.35 & 3.81 & -0.27 & 4.42 & 2.07 & $12.0 \mathrm{~N} / 0.75 \mathrm{P}$ & 0.15 & -1.70 & 4.24 & 0.61 & 3.32 & 1.13 & -6.47 & -4.23 \\
\hline $12.0 \mathrm{~N} / 0.75 \mathrm{P}$ & 0.03 & -0.65 & 1.93 & 0.14 & -1.39 & 0.54 & 21.16 & 3.32 & $12.0 \mathrm{~N} / 0.75 \mathrm{P}$ & 0.23 & 1.12 & 4.87 & 0.56 & 2.70 & -0.63 & 1.78 & 14.98 \\
\hline $12.0 \mathrm{~N} / 0.75 \mathrm{P}$ & 0.06 & -0.69 & 3.35 & 0.71 & -0.74 & 0.00 & 16.00 & 4.73 & $12.0 \mathrm{~N} / 0.75 \mathrm{P}$ & 0.64 & 1.10 & 11.32 & 1.34 & -0.67 & -0.88 & 5.09 & 12.60 \\
\hline $12.0 \mathrm{~N} / 0.75 \mathrm{P}$ & 0.06 & 3.61 & -0.10 & 0.29 & -4.41 & 0.19 & 0.53 & -5.63 & - & - & - & - & - & - & - & - & \\
\hline $17.65 \mathrm{~N} / 1.10 \mathrm{P}$ & 0.54 & 4.14 & 4.07 & 0.83 & 3.15 & -0.38 & 7.77 & 5.48 & $17.65 \mathrm{~N} / 1.10 \mathrm{P}$ & 0.76 & 4.24 & 2.34 & 0.75 & -1.35 & -0.52 & -7.40 & 8.06 \\
\hline $12.0 \mathrm{~N} / 0.25 \mathrm{P}$ & -0.28 & -1.44 & -8.30 & -1.14 & -4.86 & 0.49 & -19.47 & 3.39 & $2.00 \mathrm{~N} / 0.75 \mathrm{P}$ & -1.01 & -1.58 & -4.51 & -1.14 & -2.27 & -0.48 & -15.10 & -18.80 \\
\hline $12.0 \mathrm{~N} / 0.25 \mathrm{P}$ & -0.26 & -0.46 & -6.51 & -0.99 & -4.39 & 0.56 & -17.77 & -6.21 & $2.00 \mathrm{~N} / 0.75 \mathrm{P}$ & -1.04 & -1.89 & -14.10 & -2.12 & -9.27 & 3.42 & -21.78 & -19.77 \\
\hline $12.0 \mathrm{~N} / 0.25 \mathrm{P}$ & -0.30 & -1.09 & -2.00 & -0.67 & -0.10 & 0.13 & -17.16 & -4.46 & $2.00 \mathrm{~N} / 0.75 \mathrm{P}$ & -1.09 & -2.20 & -8.85 & -1.38 & -18.84 & -2.18 & -15.68 & -14.42 \\
\hline $6.35 \mathrm{~N} / 1.10 \mathrm{P}$ & -0.29 & -0.79 & -0.47 & -0.35 & -2.48 & -0.51 & 5.83 & -4.87 & $4.00 \mathrm{~N} / 0.75 \mathrm{P}$ & -0.62 & -0.52 & -5.46 & -1.05 & -3.88 & -0.65 & 1.07 & -9.07 \\
\hline $12.0 \mathrm{~N} / 1.25 \mathrm{P}$ & 0.03 & 0.28 & 4.86 & 0.58 & 2.84 & -0.41 & 0.59 & 0.15 & $4.00 \mathrm{~N} / 0.75 \mathrm{P}$ & -0.88 & -0.88 & -10.83 & -1.58 & -4.78 & 0.25 & -21.95 & -9.19 \\
\hline $12.0 \mathrm{~N} / 1.25 \mathrm{P}$ & 0.16 & -0.73 & 0.39 & 0.10 & 5.46 & 0.24 & 10.52 & -2.35 & $4.00 \mathrm{~N} / 0.75 \mathrm{P}$ & -0.22 & -0.79 & -6.56 & -1.54 & -2.37 & -1.60 & 3.12 & -9.56 \\
\hline $12.0 \mathrm{~N} / 1.25 \mathrm{P}$ & 0.38 & -1.32 & 2.71 & 0.19 & 4.69 & 0.06 & 6.48 & -6.93 & $6.00 \mathrm{~N} / 1.03 \mathrm{P}$ & -0.65 & -2.14 & -12.28 & -1.73 & -0.08 & -1.34 & -23.60 & -8.95 \\
\hline $12.0 \mathrm{~N} / 1.75 \mathrm{P}$ & 0.13 & -2.16 & -1.61 & -0.40 & -2.89 & 0.04 & 3.00 & 4.16 & $6.35 \mathrm{~N} / 0.40 \mathrm{P}$ & -0.49 & 1.26 & 0.10 & -0.25 & 0.53 & 0.11 & -5.21 & -0.84 \\
\hline $12.0 \mathrm{~N} / 1.75 \mathrm{P}$ & -0.27 & -0.83 & -4.35 & -0.19 & 4.07 & -0.12 & -15.74 & 4.07 & $17.65 \mathrm{~N} / 0.40 \mathrm{P}$ & 0.91 & -0.79 & 7.45 & 1.17 & 6.22 & -0.30 & 15.35 & 16.30 \\
\hline \multirow[t]{3}{*}{$12.0 \mathrm{~N} / 1.75 \mathrm{P}$} & 0.23 & -0.70 & 1.66 & 0.26 & -2.75 & 0.51 & -6.15 & 3.07 & $20.0 \mathrm{~N} / 0.75 \mathrm{P}$ & 0.94 & 1.62 & 10.52 & 2.08 & 7.68 & 1.80 & 39.38 & 19.81 \\
\hline & & & & & & & & & $20.0 \mathrm{~N} / 0.75 \mathrm{P}$ & 1.05 & 1.85 & 7.29 & 1.51 & 1.51 & -0.12 & 17.43 & -1.03 \\
\hline & & & & & & & & & $20.0 \mathrm{~N} / 0.75 \mathrm{P}$ & 1.31 & 1.30 & 14.47 & 2.76 & 4.16 & 0.78 & 33.98 & 24.11 \\
\hline$r\left(\mathrm{PO}_{4}^{3}\right)=$ & 0.45 & -0.10 & 0.37 & 0.41 & 0.39 & -0.24 & 0.25 & 0.31 & $r\left(\mathrm{NO}_{3}^{-}\right)=$ & 0.97 & 0.70 & 0.87 & 0.94 & 0.71 & 0.18 & 0.80 & 0.86 \\
\hline
\end{tabular}
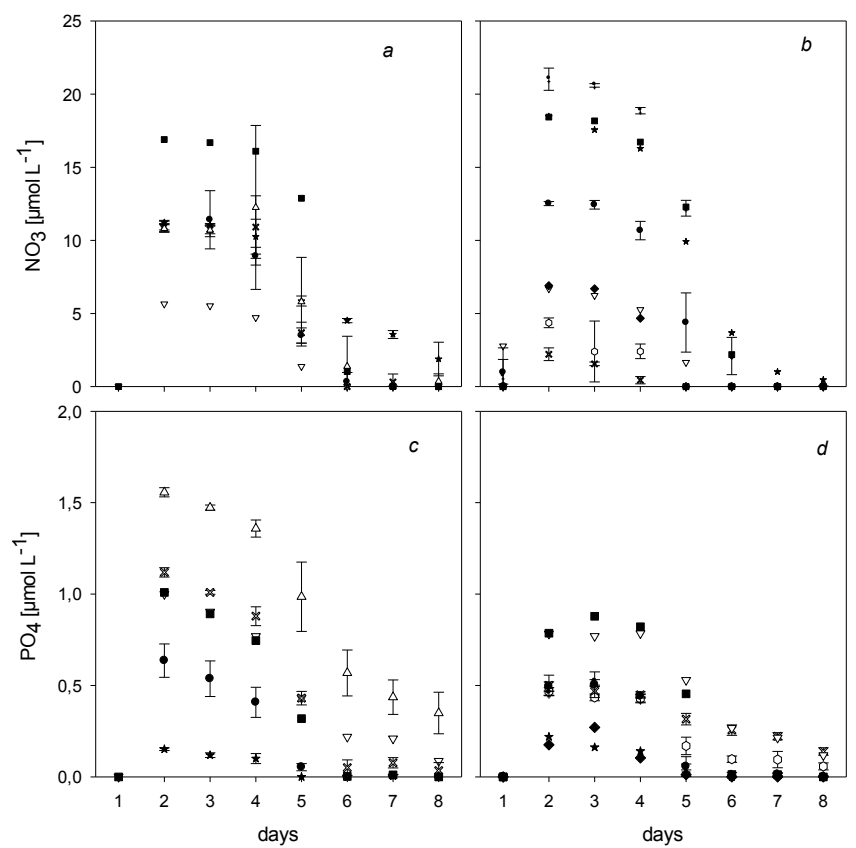

Figure 2. Nutrient concentrations during two series of mesocosm experiments with varied supply of $\mathrm{PO}_{4}^{3-}$ (Varied $P ; \mathbf{a}, \mathbf{c} ; n=16$ ) or $\mathrm{NO}_{3}^{-}$(Varied $N ; \mathbf{b}, \mathbf{d} ; n=16$ ), respectively. For treatments with identical nutrient supply, average values are given \pm 1 standard deviation (error bars). See Table 1 for explanation of symbols.

in most mesocosms (Fig. 3a, b). For Varied P, accumulation of DOC with respect to initial concentration (day 1) $(\triangle \mathrm{DOC})$ was observed, ranging from $18.8 \pm 6.7 \mu \mathrm{mol} \mathrm{L}{ }^{-1}$ $(12.0 \mathrm{~N} / 0.25 \mathrm{P})$ to $44.0 \pm 12.0 \mu \mathrm{mol} \mathrm{L}^{-1} \quad(12.0 \mathrm{~N} / 0.75 \mathrm{P})$. During Varied $N, \triangle \mathrm{DOC}$ increased also in the course of the experiment, with highest values observed at the end of the experiment, ranging from $12.1 \pm 1.1 \mu \mathrm{mol} \mathrm{L} \mathrm{L}^{-1} \mathrm{DOC}$ in the treatment with the lowest nitrate supply $(2.0 \mathrm{~N} / 0.75 \mathrm{P})$ to $74.4 \pm 16.6 \mu \mathrm{mol} \mathrm{L}^{-1}$ in $12.0 \mathrm{~N} / 0.75 \mathrm{P} 75$, the same treatment that yielded highest $\triangle \mathrm{DOC}$ during Varied $P$. MDs of DOC were not significantly correlated to the initial $\mathrm{PO}_{4}^{3-}$ supply during Varied $P$ but rather to the initial $\mathrm{NO}_{3}^{-}$supply during Varied $N(p<0.005)$, indicating a general dependence of DOC accumulation on $\mathrm{NO}_{3}^{-}$stocks (Table 2).

On day 1 , DON concentration (day 1) was $8.8 \pm 1.1$ and $11 \pm 1.5 \mu \mathrm{mol} \mathrm{L}^{-1}$ for mesocosms of Varied $P$ and Varied $N$, respectively. In both experiments, DON concentration decreased after nutrient addition (Fig. 3c, d). During Varied P, $\triangle \mathrm{DON}$ was negative in some of the mesocosms until the Chl $a$ maximum on day 5 . Values increased slowly between days 6 and 7 before a clear increase was determined for all mesocosms on day 8 with $\triangle D O N$ accumulation ranging between 1.9 and $5.9 \mu \mathrm{mol} \mathrm{L}^{-1}$ (Fig. 3c). During Varied $N$, a clear accumulation of DON was not observed, yielding values of $\triangle \mathrm{DON}$ of -6.0 to $4.8 \mu \mathrm{mol} \mathrm{L} \mathrm{L}^{-1}$ at the end of the experiment. On day 8 of both experiments, highest and lowest $\triangle \mathrm{DON}$ were determined in the treatments with the highest and lowest initial $\mathrm{NO}_{3}^{-}$supply at identical $\mathrm{PO}_{4}^{3-}$ supply, respectively. A significant correlation between the initial $\mathrm{PO}_{4}^{3-}$ or $\mathrm{NO}_{3}^{-}$supply and DON accumulation, however, was not determined (Table 2).

Both increasing DOC and decreasing DON concentrations resulted in a rise of molar [DOC]:[DON] ratios until the bloom peak during both experiments (data not shown). During Varied $P$ [DOC] : [DON] ratios were initially $10.1 \pm 0.92$, averaged for all mesocosms and ranged between 7.7 and 31 throughout the experiment, with highest values being observed just before the bloom peak. During Varied $N$, [DOC] : [DON] ratios started at $9.1 \pm 1.1$ and ranged between 6.8 and 34 throughout the experiment, with highest values also observed shortly before the bloom peak on day 6 . 

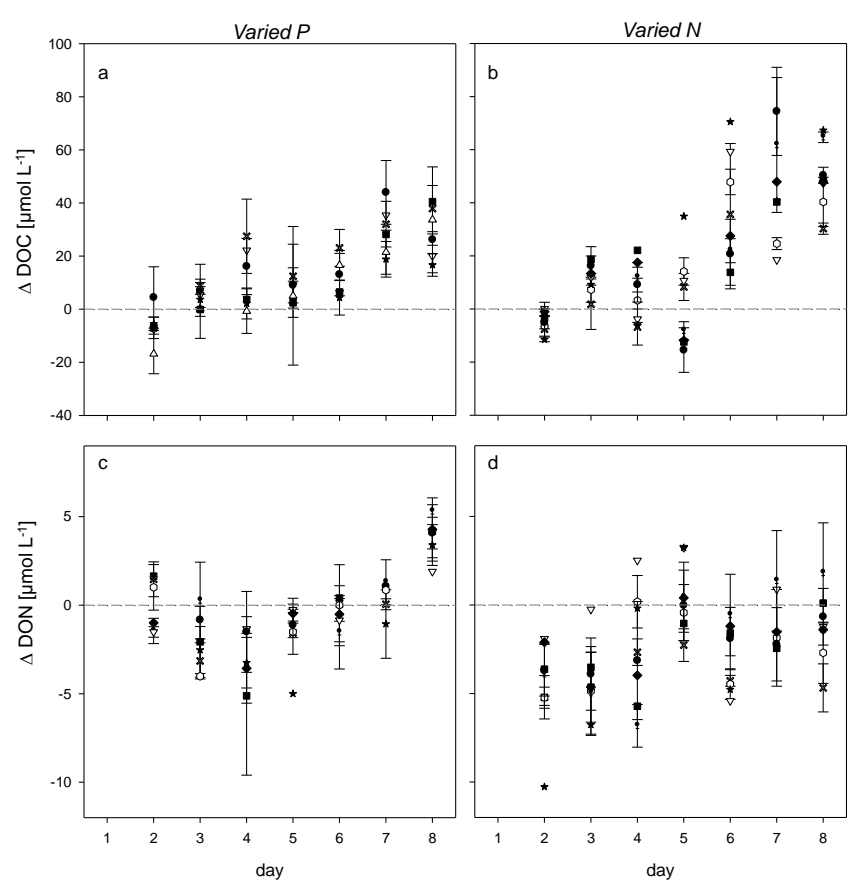

Figure 3. Changes in dissolved organic carbon $(\delta \mathrm{DOC} ; \mathbf{a}, \mathbf{b})$ and dissolved organic nitrogen $(\delta \mathrm{DON} ; \mathbf{c}, \mathbf{d})$ concentration during Varied $P(\mathbf{a}, \mathbf{c})$ and Varied $N(\mathbf{b}, \mathbf{d})$. Values are given as difference to day 1. For treatments with identical nutrient supply, average values are given \pm 1 standard deviation (error bars). The dashed line visualizes the zero value; symbols as in Table 1.

\subsection{Gel particle abundance}

Averaged for all mesocosms, initial (day 1) TEP numerical abundance was $0.97 \pm 0.64 \times 10^{7} \mathrm{~L}^{-1}$ for Varied $P$ and steadily increased to highest values between $5.9 \times 10^{7}$ and $1.5 \times 10^{8} \mathrm{~L}^{-1}$ until the end of the study (Fig. 4a). TEP total area behaved similar to TEP numerical abundance; values increased from an initial $4.46 \pm 2.36 \times 10^{7}$ to values between $3.9 \times 10^{8}$ and $7.9 \times 10^{8} \mu \mathrm{m}^{2} \mathrm{~L}^{-1}$ on day 8 (data not shown). Variation of initial $\mathrm{NO}_{3}^{-}$concentrations during Varied $\mathrm{N}$ induced clearly stronger responses in TEP formation than variation in initial $\mathrm{PO}_{4}^{3-}$ concentration (Fig. 4b). From an averaged $1.07 \pm 0.34 \times 10^{7} \mathrm{~L}^{-1}$, TEP abundance increased until day 8 to values of $1.1 \times 10^{8}-2.8 \times 10^{8} \mathrm{~L}^{-1}$. While initial numbers were in a comparable range for both experiments, the maximum TEP abundances (day 8) during Varied $N$ were about twice as high as during Varied $P$. The same holds for TEP total area: initial averaged values were only slightly higher $\left(5.04 \pm 1.43 \times 10^{7} \mu \mathrm{m}^{2} \mathrm{~L}^{-1}\right)$ than initial values during Varied $P$, but highest values more than doubled on day 8 during Varied $N$, yielding $9.6 \times 10^{8}-1.6 \times 10^{9} \mu \mathrm{m}^{2} \mathrm{~L}^{-1}$ (data not shown).

During both experiments, TEP numbers and total area increased similarly in all treatments until the $\mathrm{Chl} a$ maximum. From day 6 onwards, however, distinct differences emerged
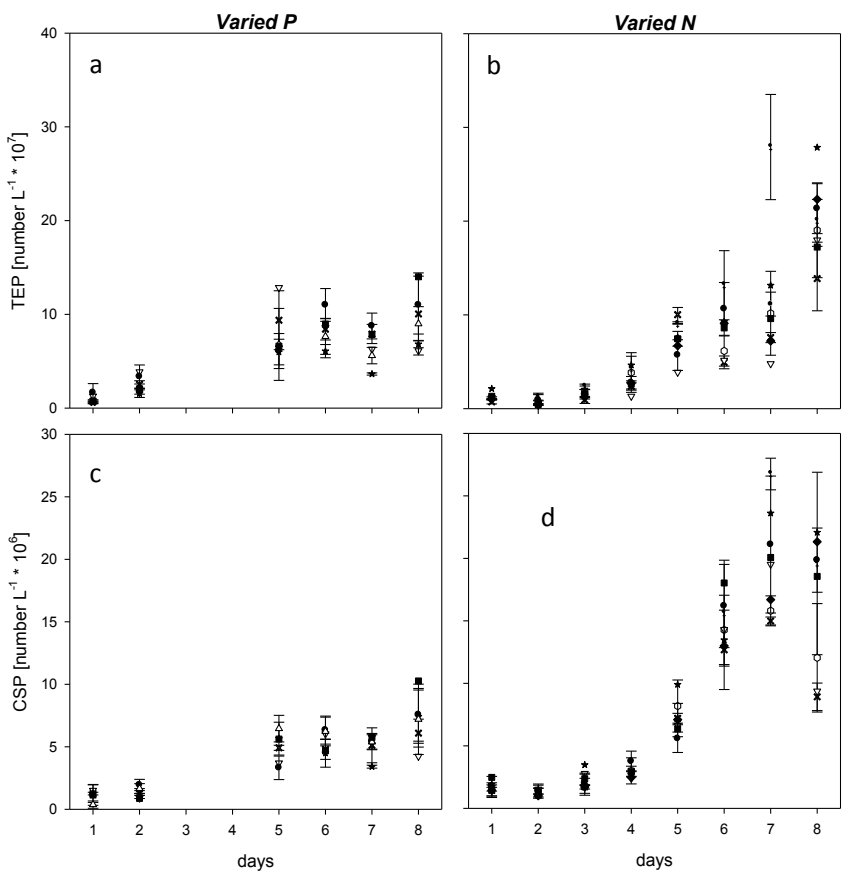

Figure 4. Temporal changes in the total numerical abundance of transparent exopolymer particles (TEP; a, b) and of Coomassie stainable particles (CSP; $\mathbf{c}, \mathbf{d})$ during Varied $P(\mathbf{a}, \mathbf{c})$ and Varied $N(\mathbf{b}, \mathbf{d})$. For treatments with identical nutrient supply, average values are given \pm 1 standard deviation (error bars). The dashed line visualizes the zero value; symbols as in Table 1.

between treatments, particularly during Varied $N$. Here, TEP abundance was significantly higher in the highest $\mathrm{NO}_{3}^{-}$treatment $(20.0 \mathrm{~N} / 0.75 \mathrm{P})$ compared to treatments amended with lower nitrate supply $(2.0 \mathrm{~N} / 0.75 \mathrm{P} ; p<0.001,4.0 \mathrm{~N} / 0.75 \mathrm{P}$; $p<0.005,6.0 \mathrm{~N} / 1.03 \mathrm{P} ; p<0.05)$. On day 7 , TEP numbers in $20.0 \mathrm{~N} / 0.75 \mathrm{P}$ reached their maximum and were significantly higher than in all other treatments $(p<0.001)$, where TEP numbers continued to increase on day 8. Like TEP numbers, TEP total area was also significantly larger in the highest $\mathrm{NO}_{3}^{-}$treatment $(20.0 \mathrm{~N} / 0.75 \mathrm{P})$ compared to $2.0 \mathrm{~N} / 0.75 \mathrm{P}$ and $6.0 \mathrm{~N} / 1.03 \mathrm{P}(p<0.01)$, showing a clear stimulation of TEP formation at higher nitrate levels.

For Varied $\mathrm{P}$, initial $\mathrm{PO}_{4}^{3-}$ concentration had on average no significant effect on MD of TEP abundance (Table 2). In contrast, a significant positive relationship between MD of TEP abundance and initial $\mathrm{NO}_{3}^{-}$supply was determined during Varied $N(p<0.001)$. This relationship, however, reversed when MDs of Chl $a$-normalized TEP concentration were considered, indicating that a relatively higher fraction of newly fixed organic carbon was partitioned into TEP at lower nitrate supply on a cellular level $(p<0.001$; data not shown).

Similar to TEP, CSP abundance and total area increased steadily over time during both mesocosm experiments, although CSP were generally less abundant than TEP (Fig. 4c, 
d). From an initial mean value of $1.06 \pm 0.61 \times 10^{6} \mathrm{~L}^{-1}$ during Varied $P$, CSP numerical abundance increased to $4.2 \times 10^{6}$ to $1.0 \times 10^{7} \mathrm{~L}^{-1}$ on day 8 . Highest CSP abundance was determined in the treatment with the highest nitrate supply $(17.65 \mathrm{~N} / 1.10 \mathrm{P})$, where CSP total area of initially $1.5 \pm 0.5 \times 10^{7} \mu \mathrm{m}^{2} \mathrm{~L}^{-1}$ increased to $4.5 \times 10^{7}$ $1.2 \times 10^{8} \mu \mathrm{m}^{2} \mathrm{~L}^{-1}$ on day 8 . Similar to TEP, a much stronger increase in CSP abundance was observed during Varied $N$. Here, CSP numbers increased from an initial average of $1.63 \pm 0.48 \times 10^{6} \mathrm{~L}^{-1}$ to highest values of $1.4 \times 10^{7}$ $2.8 \times 10^{8} \mathrm{~L}^{-1}$ on day 7 (Fig. $5 \mathrm{~d}$ ) - more than double the amount observed during Varied P. Again, highest CSP abundances were determined in replicate treatments of highest $\mathrm{NO}_{3}^{-}$supply $(20.0 \mathrm{~N} / 0.75 \mathrm{P})$, yielding $2.7 \pm 0.1 \times 10^{7} \mathrm{~L}^{-1}$.

Analysis of variance for data obtained on day 7 revealed significantly higher CSP abundances in 20.0N / 0.75P compared to $2.0 \mathrm{~N} / 0.75 \mathrm{P}(p<0.001), 4.0 \mathrm{~N} / 0.75 \mathrm{P}(p<0.001)$ and $6.35 \mathrm{~N} / 0.40 \mathrm{P}(p<0.05)$, indicating a stimulation of CSP formation at elevated initial $\mathrm{NO}_{3}^{-}$concentrations. This is in accordance with a highly significant correlation of MD of CSP abundance and initial $\mathrm{NO}_{3}^{-}$concentrations $(p<0.001$, Table 2). Findings for CSP numbers are reflected in CSP total area: highest values were also observed for the high- $\mathrm{NO}_{3}^{-}$treatment $(20.0 \mathrm{~N} / 0.75 \mathrm{P}$; $\left.213 \pm 21 \times 10^{6} \mu \mathrm{m}^{2} \mathrm{~L}^{-1}\right)$, with values significantly larger than in $2.0 \mathrm{~N} / 0.75 \mathrm{P}(p<0.005), 4.0 \mathrm{~N} / 0.75 \mathrm{P}(p<0.001)$, $6.35 \mathrm{~N} / 0.40 \mathrm{P}(p<0.001), 17.65 \mathrm{~N} / 1.10 \mathrm{P}(p<0.05)$ and $12.0 \mathrm{~N} / 0.75 \mathrm{P}$ ( $p<0.005$; data not shown). In contrast to TEP abundance, CSP number declined in most treatments on day 8 of Varied $N$ (except for 12.0N / 0.75P; only MK 1, $6.35 \mathrm{~N} / 0.40 \mathrm{P}$ and 4.0N / 0.75P; only MK 11).

\subsection{Gel particle size distributions}

At the beginning of the study, median values for TEP equivalent spherical diameter (ESD) were almost identical for Varied $P$ and Varied $N$, yielding $1.78 \pm 0.12$ and $1.79 \pm 0.08 \mu \mathrm{m}$ ESD, respectively. Except for days 6 and 8, median size of TEP was steadily increasing over time in Varied $P$, with largest particles occurring in $6.35 \mathrm{~N} / 1.10 \mathrm{P}, 12.0 \mathrm{~N} / 1.75 \mathrm{P}$ and $12.0 \mathrm{~N} / 1.25 \mathrm{P}$ on day 7 (2.28-2.30 $\mu \mathrm{m}$ ESD). On day 8, median TEP size was slightly smaller again and similar in all treatments ranging between 1.80 and $2.26 \mu \mathrm{m}$ ESD. During Varied $N$, the size of TEP remained relatively constant between days 1 and 4 and then increased until the Chl $a$ maximum. After the bloom peak, median TEP size further increased until day 6 , yielding values between 2.5 and $1.9 \mu \mathrm{m}$ ESD at the end of the experiment.

Spectral slopes describe the size-frequency distribution of particles with more negative values indicating relatively more small particles (Fig. 5) and mirrored changes in the median ESD of both types of gel particles during both experiments. Changes in size-frequency distribution of TEP were observed for Varied $P$ and Varied $N$, with slope values $(\delta)$ becoming significantly smaller during the first half
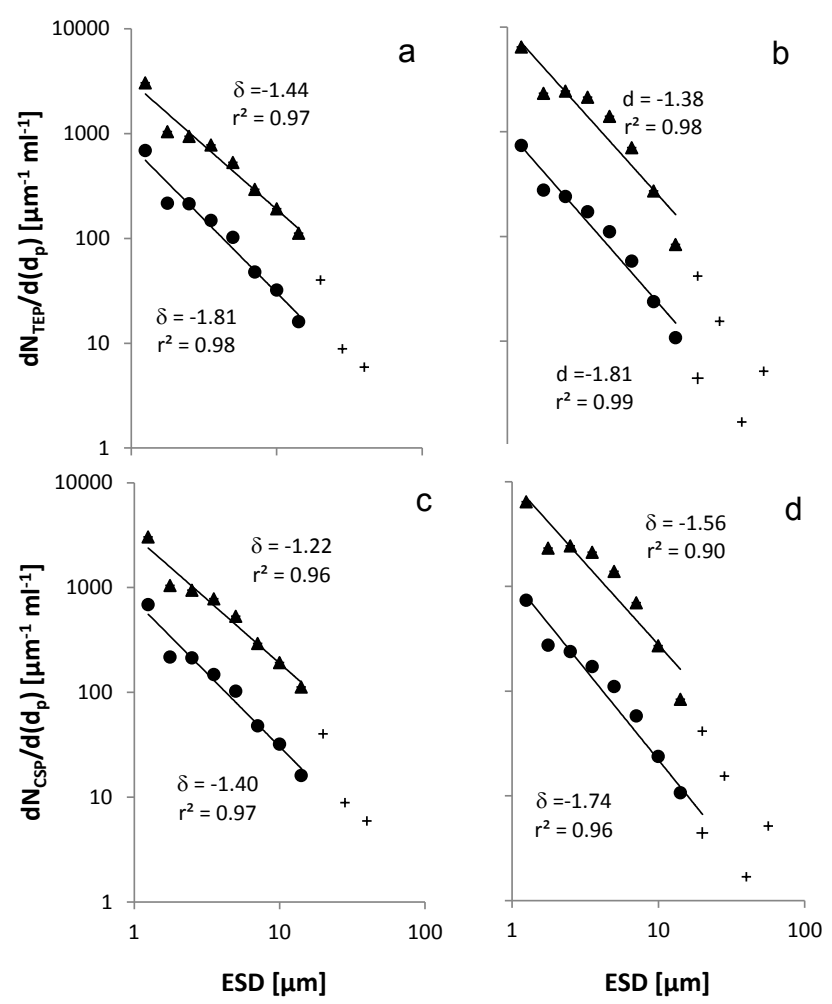

Figure 5. Size-frequency distribution of gel particles. Calculation of the size-frequency distribution slope exemplified for TEP, averaged for all mesocosms on day 1 (circles) and 8 (triangles) during Varied $P$ (a) and Varied $N$ (b), respectively, and for CSP on day 2 (circles) and 8 (triangles) during Varied $P(\mathbf{c})$ and Varied $N(\mathbf{d})$. Linear regression of $\log \left[\mathrm{d} N / \mathrm{d}\left(d_{\mathrm{p}}\right)\right]$ versus $\log \left[d_{\mathrm{p}}\right]$ was fitted to the particles in the size range of 1.05-14.14 $\mu \mathrm{m}$ ESD (solid symbols).

of both experiments ( $p<0.001$; multiple comparison, HolmŠidák; Fig. 6). Average slopes on day 1 were very similar for Varied $P$ and Varied $N$, yielding $\delta=-1.81 \pm 0.12$ and $\delta=-1.81 \pm 0.11$, respectively. Slopes increased to average $-1.44 \pm 0.06$ (Varied $P$ ) and $-1.38 \pm 0.06$ (Varied $N$ ) on day 8 of both experiments, suggesting a relative shift from smaller to larger TEP (Fig. 6a, b).

Slightly smaller than TEP size, median CSP size was on average $1.37 \pm 0.06 \mu \mathrm{m}$ ESD at the beginning of Varied $P$, and increased to values between 1.13 and $1.78 \mu \mathrm{m}$ ESD until the end of the experiment (Fig. 6c). During Varied N, median CSP size increased between day $1(1.36 \pm 0.09 \mu \mathrm{m}$ ESD $)$ and day 4 (1.34-1.85 $\mu \mathrm{m}$ ESD). In contrast to median TEP size, median CSP size decreased towards the end of the experiments and ranged between 1.18 and $1.71 \mu \mathrm{m}$ ESD on day 8 . During Varied $P$, a large variability in $\delta$ values was observed for CSP size distribution on day 1 . To estimate changes in size distribution during this experiment, data evaluation of CSP slopes was started on day 2 (Fig. 6c), when CSP size distribution was more similar between mesocosms. Like for TEP, development of CSP spectral slopes during this study 

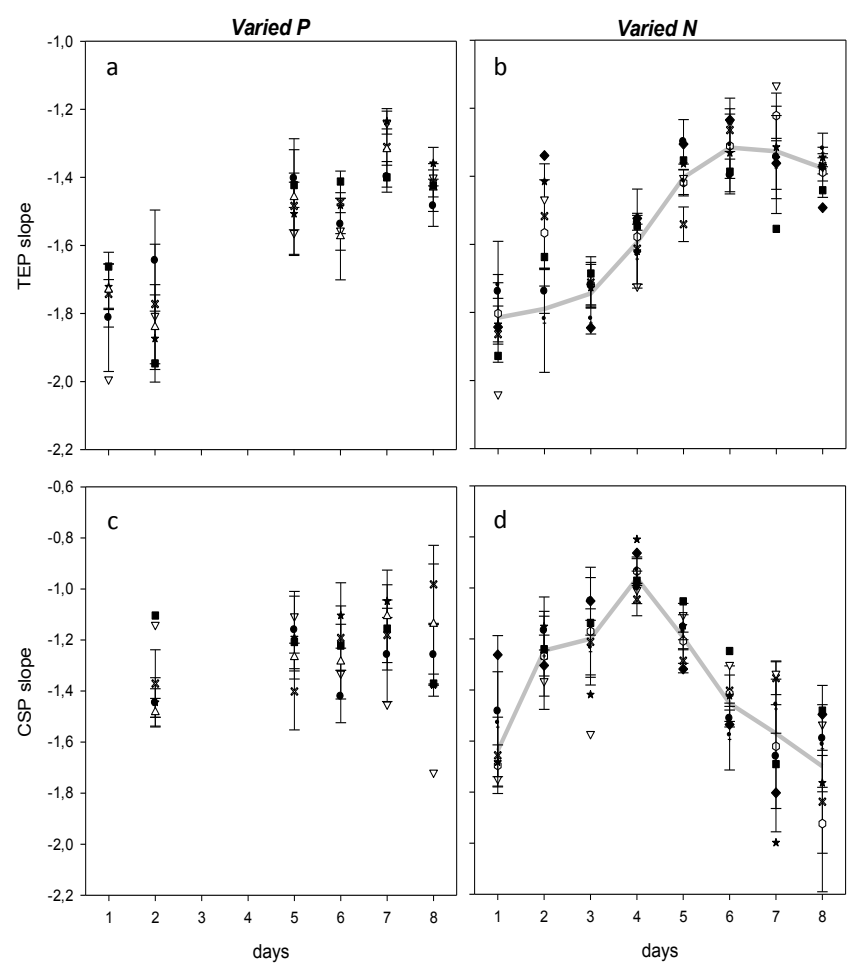

Figure 6. Changes in the slope $(\delta)$ of the size-frequency distribution of TEP $(\mathbf{a}, \mathbf{b})$ and CSP $(\mathbf{c}, \mathbf{d})$ during the mesocosm blooms. The grey lines indicate the mean value of all mesocosms on the respective day; symbols as in Table 1.

mirrored the change in median ESD size of particles. Averaged for all mesocosms, $\delta=-1.40 \pm 0.14$ was obtained on day 2 of Varied $P$, increasing steadily to $-1.24 \pm 0.23$ until day 8. The size-frequency distribution of CSP during Varied $P$ was not affected by the initial nutrient supply. For Varied $N$, initial slopes also scattered on day 1 , however not as strongly as for initial values for Varied $P$. Initial averaged slopes for all mesocosms were $-1.64 \pm 0.28$ (Fig. 6d). During days $2-4$, the overall development shows a relative increase in the slope of the size distribution during the onset of the bloom. Highest values of $\delta=-0.84$ coincided with the largest median ESD of CSP on day 4. At the time of the Chl $a$ maximum, slopes became more negative, revealing higher abundance of relatively small particles. Multiple comparison (Holm-Šidák) tests revealed significantly larger slopes for days 2 to 4 , compared to days $1,6,7$ and $8(p<0.010)$. The increase in abundance of smaller CSP continued during the bloom decay and was most pronounced in $2.0 \mathrm{~N} / 0.75 \mathrm{P}$ and $4.0 \mathrm{~N} / 0.75 \mathrm{P}$, the treatments with the lowest initial $\mathrm{NO}_{3}^{-}$ supply.

\subsection{Differences between two mesocosm experiments - a case of treatment effects?}

Although the development of gel particle abundance was rather similar for TEP and CSP during both experiments, par- ticularly until the bloom peak, abundance of gel particles was clearly higher during the second mesocosm experiment, Varied $N$, compared to Varied P (Fig. 4). Moreover, during Varied $N$, CSP increased relatively more than TEP and showed a unique change in size distributions during bloom development not observed during Varied $P$ and different from TEP.

In order to identify differences between the two series of mesocosm experiments, gel particle abundance was compared to bloom development, which also differed between the experiments.

During both experiments, gel particle dynamics were tightly coupled to the production of organic matter during bloom development (Fig. 7, Table 3). Numerical abundances of TEP and CSP were directly related to Chl $a$ concentration until the bloom peak (Fig. 7a, d). Thereby, the increase in gel particle abundance with Chl $a$ concentration was different for TEP and CSP during Varied $P$ as well as during Varied $N$. While TEP abundance increased slightly faster with Chl $a$ concentration during Varied $P$, the increase in CSP abundance with $\mathrm{Chl} a$ concentration was twice as strong during Varied $N$ compared to during Varied $P$ (Table 3). After the Chl $a$ maxima, gel particle formation continued while Chl $a$ concentrations declined, leading to higher [gel particles]: [Chl $a$ ] ratios towards the end of the experiments (Table 4). Partly decoupled from Chl $a$ concentration, gel particles remained tightly coupled to POC and PN dynamics throughout both experiments (Fig. 7b, c, e, f). Thereby, a similar coupling was observed between TEP and POC or PN concentration during both experiments, while CSP abundance increased more strongly with POC and PN concentration during Varied $N$ (Table 3). The carbon content of TEP (TEP-C) averaged for all mesocosms on day 1 was $0.61 \pm 0.29$ and $0.72 \pm 0.38 \mu \mathrm{mol} \mathrm{L}^{-1}$ for Varied $P$ and Varied $N$, respectively. During both experiments, TEP-C steadily increased along with the general abundance of TEP. Maximum TEP-C during Varied $P$ was reached on day 8 , with values of $12.6-34.9 \mu \mathrm{mol} \mathrm{L}^{-1}$ representing a share of 31$41 \mathrm{~mol} \%$ POC, or 8.4-17.6 mol \% TOC (Table 4). During Varied $N$, final TEP-C concentration contributed with an even higher proportion to the organic carbon pool, equivalent to $22.8-84 \mathrm{~mol} \%$ POC or $12-29 \mathrm{~mol} \%$ of TOC. Molar ratios of [TEP-C] : [PN] were initially below 1 and increased to an average of 2.2-3.6 during Varied $P$ and to 1.8-6.9 during Varied $N$.

A direct coupling was also observed between gel particles and bacterial abundance (Table 3). Like for POC and PN, the relative increase in gel abundance was much steeper during Varied $N$ than during Varied $P$, again showing that gel particles in general were more abundant during the second experiment. Although less pronounced than for particulate organic matter, TEP and CSP numerical abundances were also related to DOC concentration during Varied $P$ and Varied $N$ (Table 3), while no significant relationship was observed between gel particle abundance and DON concentration. In contrast to gel particles, however, DOC was not significantly 

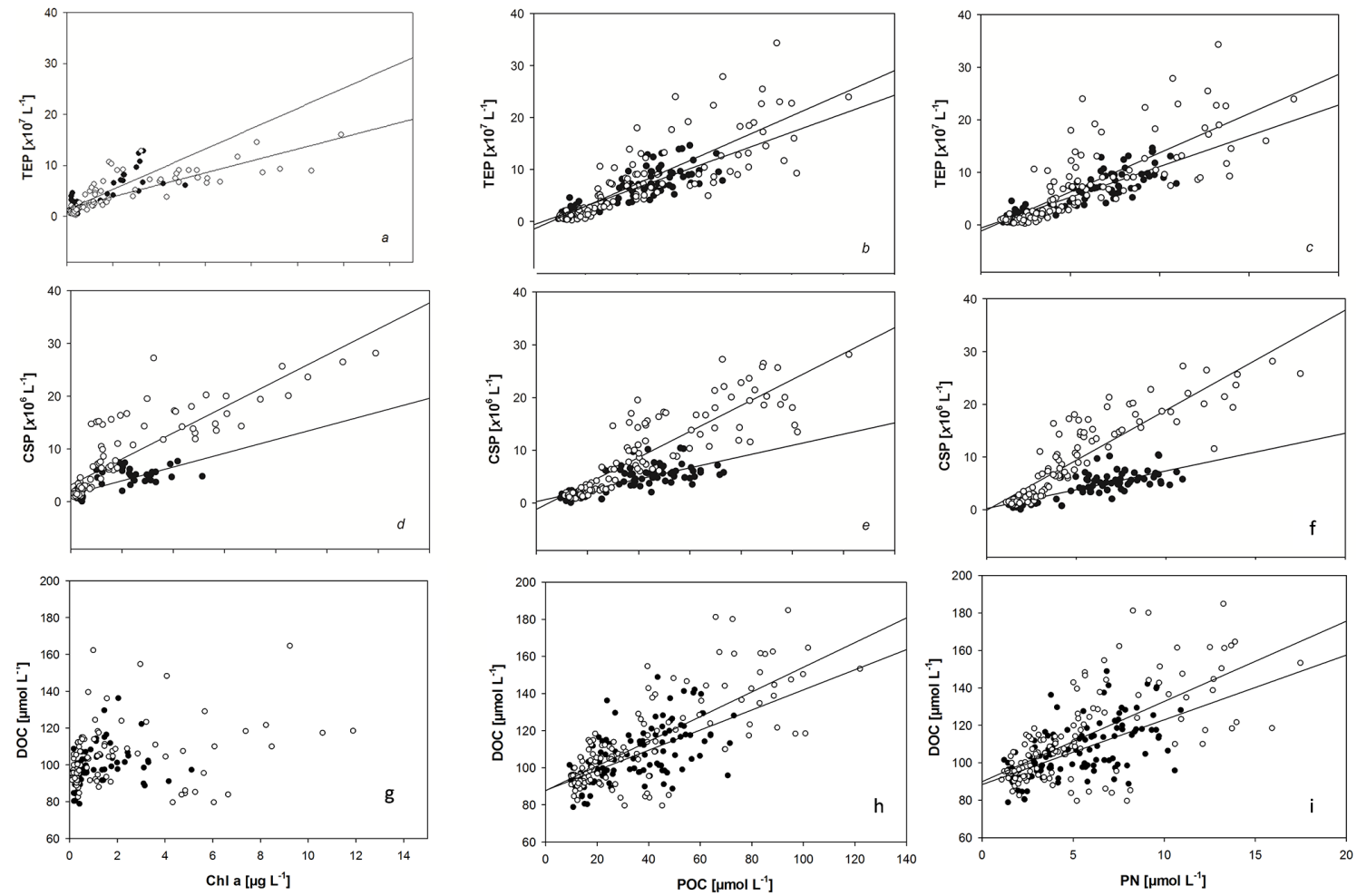

Figure 7. Relationships between organic components during Varied $P$ and Varied $N$. Solid symbols: data obtained during Varied P; open symbols: data obtained during Varied $N$. Linear regressions with Chl $a$ include data of samplings 1, 2 and 5 for Varied $P$ and 1-6 for Varied $N$. Linear regressions with POC and PN include data of all samplings. Information on regression statistics is given in Table 2.

related to $\mathrm{Chl} a$ concentration in both experiments but rather to POC and PN concentrations (Fig. 7g-i, Table 3). Differences in the relationship of DOC to POC or PN were relatively small, suggesting an only slightly higher increase in DOC with particulates during Varied $N$. DOC concentration correlated significantly with bacterial abundance (Table 3 ). The increase in DOC concentration relative to bacterial numbers was almost twice as high during Varied $N$, suggesting that bacteria did not catch up with DOC production during the second experiment.

Another comparison of both experiments can be made by relating gel particle abundance to initial [DIN] : [DIP] ratios that covered a similar range during both experiments (Fig. 8). This showed that, for similar initial nutrient ratios, maximum abundances of both TEP and CSP were generally higher during the second experiment, Varied $N$. Moreover, only during the second experiment did changes in [DIN] : [DIP] ratios have an effect on maximum gel particle abundance.

However, direct comparison of the "centerpoint" treatment $12.0 \mathrm{~N} / 0.75 \mathrm{P}$ that was realized with four replicates during Varied $P$ and three replicates during Varied $N$ showed clear differences in organic matter development during the two experiments for mesocosms that received the same nutrient addition (Fig. 9). For this treatment, $\mathrm{Chl} a$ concentration, DOC and TEP accumulated about 2 times more in the course of
Varied $N$, while the increase in CSP abundance over time was even 3-fold higher.

\section{Discussion}

\subsection{Nutrient availability and phytoplankton bloom development}

After fertilization with inorganic nutrients, phytoplankton blooms developed in all mesocosms during the two consecutive experiments conducted with natural surface water from the ETNA. Responses to varied nutrient supply became more obvious after one (or both) of the macronutrients was exhausted, resulting in a large variation in organic matter concentration among mesocosms and treatments during the bloom peak and post-bloom phases. Accumulation of organic matter during bloom development revealed a generally stronger fertilization effect after addition of different amounts of $\mathrm{NO}_{3}^{-}$in the second experiment compared to the first one with varied initial $\mathrm{PO}_{4}^{3-}$ supply. This indicates that biomass production in ETNA surface waters near Cape Verde may be limited by nitrogen rather than by phosphorus availability. However, clear differences between both experiments were also observed for mesocosms receiving the same nutrient supply. This suggests that small differences in the initial 
Table 3. Statistics for linear regression analysis of gel particle numerical abundance and DOC concentration against organic matter components during mesocosm experiments with different initial $\mathrm{PO}_{4}^{3-}\left(\right.$ Varied $\left.P ; \mu \mathrm{mol} \mathrm{L}{ }^{-1}\right)$ and $\mathrm{NO}_{3}^{-}\left(\right.$Varied $\left.N ; \mu \mathrm{mol} \mathrm{L}{ }^{-1}\right)$ concentrations. Units - TEP: $\times 10^{7} \mathrm{~L}^{-1}$; CSP: $\times 10^{6} \mathrm{~L}^{-1}$; POC: $\mu \mathrm{mol} \mathrm{L}-1 ; \mathrm{PN}: \mu \mathrm{mol} \mathrm{L}{ }^{-1} ; \mathrm{Chl} a: \mu \mathrm{g} \mathrm{L}^{-1}$; DOC $\mu \mathrm{mol} \mathrm{L}-1 ;$ bacteria: $\times 10^{6} \mathrm{~mL}^{-1} ; a$ is the slope and $b$ is the intercept; n.s. stands for "not significant". See Fig. 7 for further information.

\begin{tabular}{|c|c|c|c|c|c|c|c|c|}
\hline \multirow[b]{3}{*}{ TEP vs. } & \multicolumn{3}{|c|}{ Varied $P$} & \multirow[b]{2}{*}{$r^{2}$} & \multicolumn{4}{|c|}{ Varied $N$} \\
\hline & \multirow[t]{2}{*}{$a$} & \multirow[t]{2}{*}{$b$} & \multirow[t]{2}{*}{$n$} & & \multirow[t]{2}{*}{$a$} & \multirow[t]{2}{*}{$b$} & \multirow[t]{2}{*}{$n$} & \multirow[t]{2}{*}{$r^{2}$} \\
\hline & & & & & & & & \\
\hline Chl $a$ & $2.0 \pm 0.22$ & $1.27 \pm 0.39$ & 60 & 0.65 & $1.2 \pm 0.08$ & $1.52 \pm 0.26$ & 96 & 0.69 \\
\hline POC & $0.18 \pm 0.012$ & $-0.63 \pm 0.49$ & 89 & 0.72 & $0.22 \pm 0.13$ & $-1.5 \pm 0.60$ & 128 & 0.70 \\
\hline $\mathrm{PN}$ & $1.2 \pm 0.07$ & $-1.4 \pm 0.4$ & 89 & 0.80 & $1.5 \pm 0.1$ & $-1.2 \pm 0.7$ & 128 & 0.64 \\
\hline DOC & $0.14 \pm 0.02$ & $-8.7 \pm 2.2$ & 90 & 0.34 & $0.22 \pm 0.02$ & $-18 \pm 2.1$ & 127 & 0.54 \\
\hline Bacteria & $3.4 \pm 0.4$ & $0.78 \pm 0.67$ & 90 & 0.46 & $6.8 \pm 0.9$ & $-1.3 \pm 1.1$ & 128 & 0.32 \\
\hline \multicolumn{9}{|l|}{ CSP vs.. } \\
\hline Chl $a$ & $1.3 \pm 0.1$ & $1.4 \pm 0.3$ & 60 & 0.76 & $2.5 \pm 0.15$ & $3.2 \pm 0.5$ & 96 & 0.74 \\
\hline POC & $0.11 \pm 0.01$ & $0.3 \pm 0.4$ & 89 & 0.58 & $0.25 \pm 0.01$ & $-1.2 \pm 0.6$ & 112 & 0.77 \\
\hline $\mathrm{PN}$ & $0.7 \pm 0.06$ & $0.2 \pm 0.3$ & 89 & 0.65 & $1.9 \pm 0.09$ & $-0.1 \pm 0.6$ & 112 & 0.80 \\
\hline DOC & $0.10 \pm 0.01$ & $-6.6 \pm 1.4$ & 90 & 0.42 & $0.21 \pm 0.03$ & $-13 \pm 3.0$ & 111 & 0.35 \\
\hline Bacteria & $2.3 \pm 0.26$ & $0.63 \pm 0.43$ & 90 & 0.49 & $8.8 \pm 0.84$ & $-2.3 \pm 1.11$ & 128 & 0.47 \\
\hline \multicolumn{9}{|l|}{ DOC vs. } \\
\hline Chl $a$ & n.s & - & - & - & n.s. & - & - & - \\
\hline POC & $0.54 \pm 0.06$ & $88 \pm 2$ & 119 & 0.38 & $0.66 \pm 0.05$ & $88 \pm 2$ & 127 & 0.58 \\
\hline $\mathrm{PN}$ & $3.5 \pm 0.4$ & $88 \pm 2$ & 119 & 0.38 & $4,2 \pm 0.4$ & $90 \pm 3$ & 127 & 0.47 \\
\hline Bacteria & $11 \pm 1.5$ & $92 \pm 2$ & 119 & 0.31 & $21 \pm 3.1$ & $88 \pm 4$ & 127 & 0.27 \\
\hline
\end{tabular}

conditions of experiments with natural communities, such as during this mesocosm study, can significantly impact the outcome of biogeochemical responses.

Moderate variations in responses of planktonic food webs and associated biogeochemical cycling to the same nutrient treatment have been observed previously for mesocosm experiments conducted at different marine ecosystem sites, but a coherent picture of nitrogen stimulation was clearly demonstrated (Olsen et al., 2006; Vadstein et al., 2012).

During this study, phytoplankton abundance was lower during the early days of Varied $N$, while bacterial abundance was higher, despite sampling of initial waters at the same location and within a time difference of only a few days. Moreover, differences between Varied $N$ and $P$ were identified for the initial community composition of diazotrophs (Meyer et al., 2015). We cannot fully exclude that these differences in the initial conditions generally affected the sensitivity to nutrient addition, regardless of the varied nutrient concentration, and were also responsible for the higher response in mesocosms where the same nutrient treatment was applied. However, the clear increase in organic matter accumulation with increasing initial $\mathrm{NO}_{3}^{-}$concentration is in accordance with previous findings (Franz et al., 2012a) and strongly suggests that ecosystems in the ETNA are controlled by $\mathrm{NO}_{3}^{-}$ rather than by $\mathrm{PO}_{4}^{3-}$ availability.

It should be kept in mind that mesocosm experiments such as conducted during this study can only capture a transient re- sponse to perturbation, such as nutrient addition, and mainly give insights into short-term effects on processes. Extrapolating from mesocosm experiments to long-term responses of natural systems is not straightforward. Hence, although the response to $\mathrm{NO}_{3}^{-}$addition during the second experiment was pronounced, it represents only one possible outcome. The observed differences for the $12.0 \mathrm{~N} / 0.75 \mathrm{P}$ treatment indicate that the response of an ecosystem to nutrient supply may vary even in a comparatively stable environment like the ETNA. Clearly, a better knowledge of the impact of ecological variability, e.g. plankton community structure, diversity and acclimation potential, on biogeochemical processes is needed to fully explain differences in the response size to perturbation.

\subsection{Nutrient effects on gel particle dynamics}

Previous studies on TEP and CSP in marine systems have suggested that the rate of gel particle formation depends on the amount and chemical quality of dissolved precursors (Engel et al., 2004a; Mari and Robert, 2008; Chow et al., 2015). For extracellular organic matter released by bacterioand phytoplankton, the chemical composition and molecular weight of compounds varies among species, and is also dependent on environmental conditions and physiological status (Aluwihare and Repeta, 1999; Grossart et al., 2007; Borchard and Engel, 2015). Because extracellular release is a 
Table 4. Ratios of estimated carbon content of transparent exopolymer particles (TEP-C) to concentrations of particulate organic carbon (POC), total organic carbon (TOC), particulate nitrogen (PN) and Chl $a$. Average values (mean for TEP-C, median for ratios) are given for replicate treatments on day 1 and 8 during Varied $P$ and Varied $N$, respectively.

\begin{tabular}{|c|c|c|c|c|c|c|c|}
\hline Sampling & $n$ & Treat_ID & $\begin{array}{r}\text { TEP-C } \\
{\left[\mu \mathrm{mol} \mathrm{L}^{-1}\right]}\end{array}$ & $\begin{array}{r}\text { TEP-C : POC } \\
{[\mathrm{mol} \%]}\end{array}$ & $\begin{array}{r}\text { TEP-C : TOC } \\
{[\mathrm{mol} \%]}\end{array}$ & $\begin{array}{r}\text { TEP-C : PN } \\
{[\mathrm{mol}: \mathrm{mol}]}\end{array}$ & $\begin{array}{l}\text { TEP-C : Chl } a \\
{\left[\mu \mathrm{M}: \mu \mathrm{g} \mathrm{L}^{-1}\right]}\end{array}$ \\
\hline \multicolumn{8}{|l|}{ Varied $P$} \\
\hline Day 1 & 3 & $12.0 \mathrm{~N} / 0.25 \mathrm{P}$ & 0.52 & 3.01 & 0.48 & 16.3 & 0.25 \\
\hline 1 & 4 & $12.0 \mathrm{~N} / 0.75 \mathrm{P}$ & 0.40 & 3.12 & 0.36 & 3.4 & 0.26 \\
\hline 1 & 1 & $6.35 \mathrm{~N} / 1.10 \mathrm{P}$ & 0.98 & 5.98 & 0.83 & 13.0 & 0.45 \\
\hline 1 & 1 & $17.65 \mathrm{~N} / 1.10 \mathrm{P}$ & 0.52 & 4.14 & 0.45 & 7.5 & 0.28 \\
\hline 1 & 3 & $12.0 \mathrm{~N} / 1.25 \mathrm{P}$ & 0.49 & 3.99 & 0.46 & 4.7 & 0.29 \\
\hline 1 & 3 & $12.0 \mathrm{~N} / 1.75 \mathrm{P}$ & 0.55 & 5.12 & 0.50 & 4.4 & 0.38 \\
\hline Day 8 & 3 & $12.0 \mathrm{~N} / 0.25 \mathrm{P}$ & 13 & 41 & 8.4 & 2.21 & 25 \\
\hline 8 & 4 & $12.0 \mathrm{~N} / 0.75 \mathrm{P}$ & 16 & 15 & 10.4 & 2.62 & 28 \\
\hline 8 & 1 & $6.35 \mathrm{~N} / 1.10 \mathrm{P}$ & 21 & 28 & 14.8 & 2.85 & 63 \\
\hline 8 & 1 & $17.65 \mathrm{~N} / 1.10 \mathrm{P}$ & 22 & 31 & 13.3 & 2.77 & 61 \\
\hline 8 & 3 & $12.0 \mathrm{~N} / 1.25 \mathrm{P}$ & 18 & 26 & 9.9 & 2.79 & 32 \\
\hline 8 & 3 & $12.0 \mathrm{~N} / 1.75 \mathrm{P}$ & 35 & 19 & 17.6 & 3.63 & 83 \\
\hline \multicolumn{8}{|l|}{ Varied $N$} \\
\hline Day 1 & 3 & $2.0 \mathrm{~N} / 0.75 \mathrm{P}$ & 0.36 & 3.07 & 0.29 & 0.21 & 2.04 \\
\hline 1 & 3 & $4.0 \mathrm{~N} / 0.75 \mathrm{P}$ & 0.62 & 4.90 & 0.54 & 0.36 & 3.84 \\
\hline 1 & 1 & $6.0 \mathrm{~N} / 1.03 \mathrm{P}$ & 0.50 & 4.99 & 0.48 & 0.41 & 4.18 \\
\hline 1 & 1 & $6.35 \mathrm{~N} / 0.40 \mathrm{P}$ & 0.51 & 4.56 & 0.47 & 0.35 & 3.63 \\
\hline 1 & 3 & $12.0 \mathrm{~N} / 0.75 \mathrm{P}$ & 0.88 & 7.34 & 0.90 & 0.66 & 5.16 \\
\hline 1 & 1 & $17.65 \mathrm{~N} / 0.40 \mathrm{P}$ & 1.77 & 14 & 1.67 & 1.12 & 9.33 \\
\hline 1 & 1 & $17.65 \mathrm{~N} / 1.10 \mathrm{P}$ & 0.97 & 9.32 & 0.91 & 0.66 & 7.43 \\
\hline 1 & 3 & $20.0 \mathrm{~N} / 0.75 \mathrm{P}$ & 0.75 & 4.86 & 0.68 & 0.40 & 4.37 \\
\hline Day 8 & 3 & $2.0 \mathrm{~N} / 0.75 \mathrm{P}$ & 25 & 52 & 12.0 & 3.42 & 47 \\
\hline 8 & 3 & $4.0 \mathrm{~N} / 0.75 \mathrm{P}$ & 46 & 82 & 22.4 & 6.61 & 48 \\
\hline 8 & 1 & $6.0 \mathrm{~N} / 1.03 \mathrm{P}$ & 35 & 87 & 18.9 & 6.88 & 36 \\
\hline 8 & 1 & $6.35 \mathrm{~N} / 0.40 \mathrm{P}$ & 37 & 53 & 17.3 & 4.03 & 45 \\
\hline 8 & 3 & $12.0 \mathrm{~N} / 0.75 \mathrm{P}$ & 40 & 43 & 15.6 & 3.51 & 43 \\
\hline 8 & 1 & $17.65 \mathrm{~N} / 0.40 \mathrm{P}$ & 68 & 93 & 29.1 & 6.36 & 81 \\
\hline 8 & 1 & $17.65 \mathrm{~N} / 1.10 \mathrm{P}$ & 23 & 26 & 9.7 & 1.79 & 14 \\
\hline 8 & 3 & $20.0 \mathrm{~N} / 0.75 \mathrm{P}$ & 42 & 47 & 16.1 & 3.16 & 19 \\
\hline
\end{tabular}

major source for gel particle precursors, factors influencing this release likely also affect marine gel particle formation.

During this study, a clear accumulation of DOC was observed along with biomass build-up in all mesocosms, indicating that the rate of DOC release exceeded DOC loss processes such as coagulation into gel particles or microbial uptake and respiration. Higher $\triangle D O C$ values were observed shortly after the Chl $a$ peak, coinciding with nutrient concentrations being strongly reduced. Both enhanced extracellular release of DOC and "malfunctioning" of the microbial loop, i.e. reduced microbial uptake and respiration of DOC by bacteria, have been suggested to explain DOC accumulation in the ocean, particularly at times when inorganic nutrients become depleted (Myklestad, 1974; Biddanda and Benner, 1997; Thingstad et al., 1997; Engel et al., 2004b). During this study, DOC accumulation was significantly related to the initial $\mathrm{NO}_{3}^{-}$concentration during Varied $N$, suggesting a depen- dence on the trophic status, although no direct relationship to Chl $a$ concentration was observed. Higher accumulation of DOC with increasing nitrogen load has been observed during previous mesocosm experiments and explained by a combination of production and recycling of DOC being higher at higher microbial biomass (Vadstein et al., 2012). In addition, phosphorus limitation may have reduced bacterial utilization of DOC in mesocosms with high initial [DIN]: [DIP] ratios and below detection levels of $\mathrm{PO}_{4}^{3-}$ after the bloom, when highest accumulation rates of DOC occurred.

In contrast to DOC, no accumulation of DON was observed in the course of the experiments in almost all mesocosms, except for the last day of Varied $P$ and for those treatments receiving highest $\mathrm{NO}_{3}^{-}$additions during Varied $N$. This indicates that loss processes such as microbial utilization of organic nitrogen forms or partitioning of DON into CSP exceeded DON release during this study. 

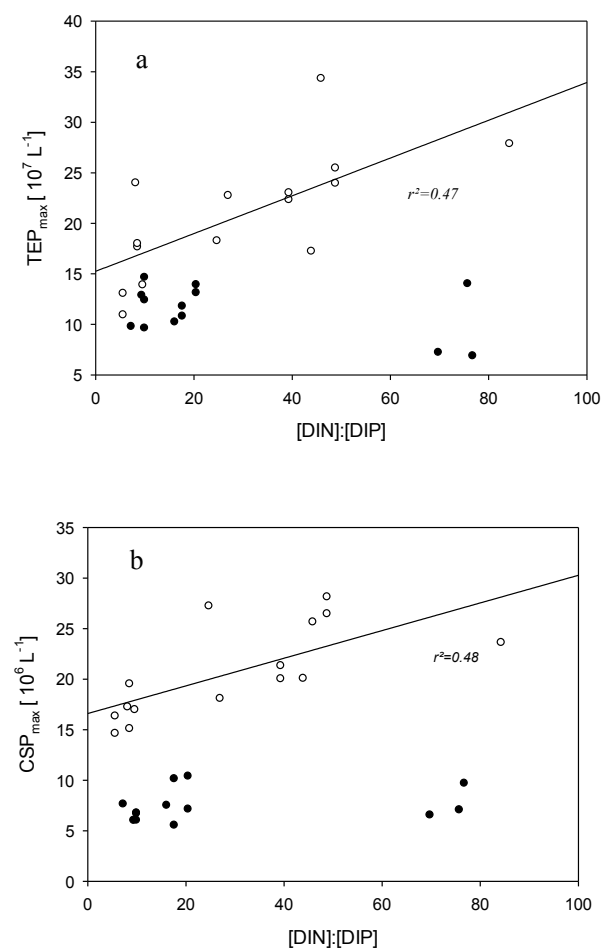

Figure 8. The maximum numerical abundance of TEP (a) and CSP (b) in the mesocosms increased with the initial (day 1) [DIN] : [DIP] ratio during Varied $N$ (open symbols), but not during Varied $P$ (solid symbols).

In general, little is known about gel particle production at tropical open-ocean sites. To the best of our knowledge, this is the first report on TEP and CSP abundance in the ETNA. Data on TEP-C concentration observed during our study (Table 4), however, agree well with observations from Wurl et al. (2011), who determined $<2$ to $40 \mu \mathrm{mol} \mathrm{CL^{-1 }}$ for TEP in surface waters of the tropical North Pacific (offshore of Hawaii).

Like DOC, gel particle abundance during this study was strongly related to the general build-up and decay of autotrophic biomass. Thereby, a significant impact of initial $\mathrm{NO}_{3}^{-}$supply on gel particle abundance, especially on CSP, was observed during Varied $N$, as well as a general increase in the maximum abundance of gel particles with the initial [DIN] : [DIP] ratio.

An increase in TEP formation, when phytoplankton was grown at higher $\mathrm{NO}_{3}^{-}$concentration, is in accordance with earlier observations made during culture and mesocosm experiments (Corzo et al., 2000; Pedrotti et al., 2010) and has been explained by higher biomass production at higher nutrient loads; a larger biomass leads to a higher amount of released polysaccharides when the autotrophic biomass runs into nutrient limitation. A general relationship between TEP and autotrophic biomass concentration, e.g. determined as Chl $a$, has been observed before (Passow, 2002; Beauvais
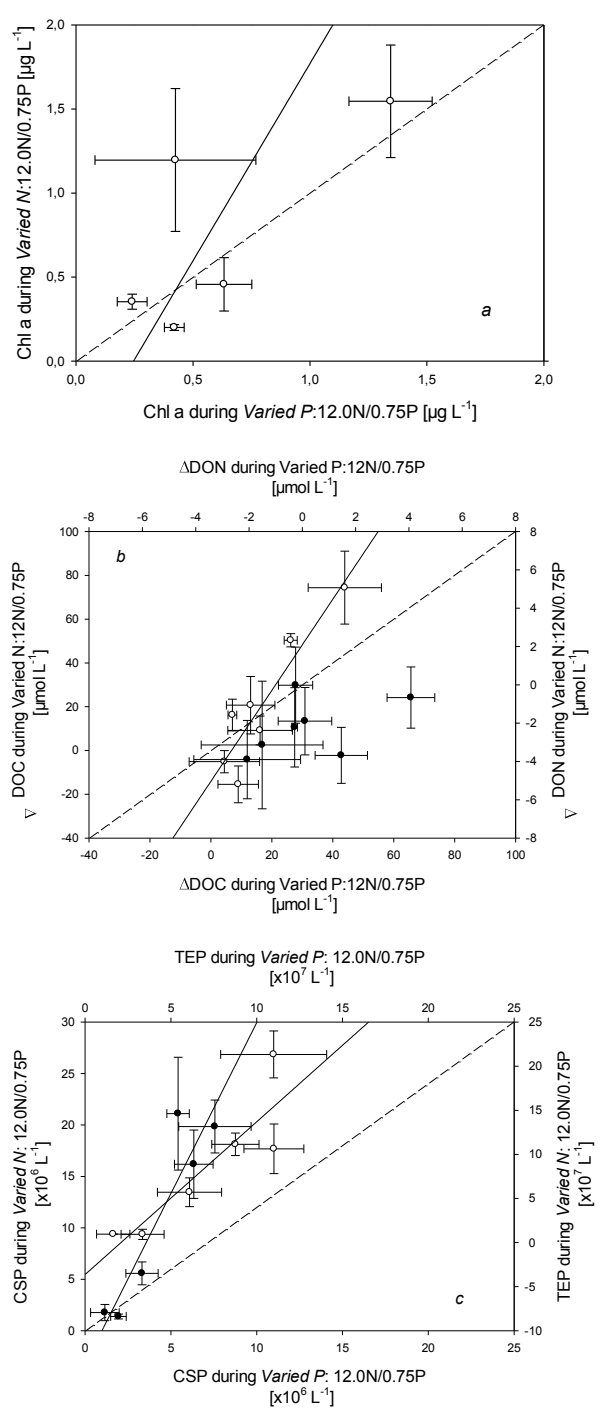

Figure 9. Comparison of Chl $a$ concentration (a), accumulation of DOC (b, open symbols) and DON (b, solid symbols), and abundance of TEP (c, open symbols) and CSP (c, solid symbols) observed in the course of the two mesocosm experiments for the treatment 12.0N / 0.75P. Direct relationships ( $\left[y_{\text {Varied } N}\right]$ $=a[\times$ Varied $P]+b)$ were observed for Chl $a$, with $a=2.3 \pm 0.2$, $r^{2}=0.94, n=8$; DOC with $a=2.1 \pm 0.4, r^{2}=0.84, n=8$; TEP with $a=1.7 \pm 0.4, r^{2}=0.78, n=6$; and CSP with $a=3.3 \pm 0.7$, $r^{2}=0.86, n=6$. Symbols represent mean values of three mesocosms (Varied $P$ ) or four mesocosms (Varied $N$ ) with \pm 1 standard deviation (error bars).

et al., 2003). Furthermore, species- or physiology-specific variations in TEP formation by phytoplankton were observed (Berman and Viner-Mozzini, 2001; Claquin et al., 2008; Passow, 2002). During this study, gel particles and Chl $a$ dynamics were decoupled after the Chl $a$ peak. Hence, despite the general observation that higher autotrophic biomass leads to more gel particles, temporal developments of Chl $a$ and gel particle concentration may contrast between bloom build-up 
and decay. This is in accordance with earlier studies showing that POC, TEP and CSP concentration continued to increase after the Chl $a$ peak (Alldrege et al., 1995; Engel, 2002; Logan et al., 1994; Mari and Kiørboe, 1996) and can be explained by the "carbon-overflow" theory (Schartau et al., 2007; Kreus et al., 2015).

During the post-bloom phase, a large proportion of organic carbon was thus channeled to the POC pool in the form of TEP. Carbon contained in TEP accounted for $0.5 \mu \mathrm{mol} \mathrm{C}$ (initial days) to $\sim 68 \mu \mathrm{mol} \mathrm{C}$ (final days), indicating a much higher DOC production than derived from $\triangle \mathrm{DOC}$ alone. The ratio of [TEP-C] : [POC] strongly increased during Varied $N$, yielding values of up to $93 \%$. Even though these values are within the range of earlier findings (Engel and Passow, 2001; Pedrotti, 2010), an underestimation of POC, and hence overestimation of the [TEP-C]:[POC] ratio, seems likely, because a large proportion of TEP was in the size range 1$2 \mu \mathrm{m}$ ESD and may not be retained on GF/F filters (nominal pore size $0.7 \mu \mathrm{m}$ ), due to their flexible and non-spherical structure (Engel and Passow, 2001; Pedrotti, 2010). In addition, TEP-C calculation by use of an empirical relationship to TEP size previously established from phytoplankton cultures could overestimate carbon content of naturally occurring TEP at this site.

A recent study by Rahav et al. (2013) suggested that bacterial diazotrophs in aphotic, DIN-rich layers of the Red Sea and eastern Mediterranean Sea benefit from TEP as an organic carbon source, resulting in an increase in aphotic nitrogen fixation with TEP concentration. For the ETNA, unicellular heterotrophic diazotrophs are readily abundant, also below the euphotic zone in high-DIN waters (Langlois et al., 2005), and contribute substantially to total nitrogen fixation of the system (Agawin et al., 2014). High TEP production by surface phytoplankton communities in the ETNA as observed during this study, and settling of TEP to aphotic layers, may therefore provide an important labile carbon source for sustaining heterotrophic nitrogen fixation.

While the importance of TEP formation for converting DOC to POC, and related consequences for carbon cycling and export, has been highlighted over the past decades (Alldrege et al., 1995; Passow, 2002; Engel et al., 2004a; Arrigo, 2007), little is known about the role of CSP, in organic carbon and more importantly in organic nitrogen cycling. It is likely that CSP play a significant role for nitrogen cycling, contributing to DON to PN conversion and to the PN pool as well as providing a nitrogenous resource for auto- and heterotrophic growth. During this study, clearly higher accumulation of CSP relative to Chl $a$ was observed during Varied $N$, i.e. when a surplus of inorganic nitrogen was available. As a consequence, CSP contributed more to POC and PON increase during Varied $N$ than during Varied $P$. This suggests that higher inorganic nitrogen supply favors production of extracellular PON, which may be subject to bacterial utilization at a later time. Because CSP are proteinaceous particles, their export to depth, e.g. by physical trans- port or as part of sinking aggregates, may provide important amino acids for microorganisms in aphotic zones, including denitrifying and anammox bacteria. Since labile amino acids have been suggested to be one important factor limiting organic matter degradation in oxygen minimum zones (Pantoja et al., 2004, 2009), a supply with CSP from the photic zone may also affect total carbon remineralization and thus oxygen consumption at deeper depths. Our results furthermore suggest that CSP as proteinaceous particles may include an important fraction of organic nitrogen in the size fraction typically attributed to bacteria.

\subsection{Formation, aggregation and degradation of gel particles - insights from size-frequency distributions}

Changes in the size-frequency distribution of TEP during this study revealed an increase in the proportion of larger particles in the course of phytoplankton blooms, indicating TEP aggregation rather than degradation during both experiments. For CSP, decreasing slopes together with a strong increase in total abundance revealed an increasing number of smaller particles during Varied $N$, indicating new formation of CSP during the phytoplankton bloom and post-bloom periods. Occurrence of CSP at the time or depth of the Chl $a$ maxima has also been observed during previous studies (CisternasNovoa et al., 2014, 2015). A clear indication of aggregation processes, i.e. decreasing slopes as for TEP, was not observed for CSP. This is in accordance with findings of Prieto et al. (2002), who suggested that CSP are less involved in aggregate formation during diatom blooms than TEP. CSP number and total area decreased at the end of Varied $N$ (day 8), suggesting that loss processes exceeded new CSP formation.

TEP and CSP both represent hotspots for microbial activity (Azam et al., 1983; Grossart et al., 1998; Bar-Zeev et al., 2009). However, CSP are, as per definition, proteinaceous particles and thus expected to include high amounts of labile $\mathrm{N}$ compounds. The observed decrease in CSP abundance at day 8 of Varied $N$ can therefore be explained by bacterial degradation in order to liberate $\mathrm{N}$, as suggested earlier (Long and Azam, 1996). Bacteria cell numbers sharply increased from day 5 onwards during both experiments, along with the strongest increase in gel particle abundance.

\section{Conclusions}

Gel particles can represent a substantial fraction of organic particles in ETNA ecosystems after nutrient supply, e.g. deep upwelling of water masses. Increasing $\mathrm{NO}_{3}^{-}$relative to $\mathrm{PO}_{4}^{3-}$ concentration favors gel particle formation. Consequently, it may be expected that a reduction of $\mathrm{NO}_{3}^{-}$surface water concentrations as a result of increasing ocean anoxia will diminish the abundance of marine gel particles, particularly 
CSP, with potential implications for aggregation, export and turnover processes of organic matter in the water column. Particle dynamics of TEP and CSP differ during bloom development; while TEP seem to be more prone to aggregation, potentially enhancing export of organic matter, CSP appear to be a better organic substrate for heterotrophs and may decompose within a few days. Because TEP and CSP are part of the bulk POC and PN pools, changes in the balance of TEP and CSP formation processes such as induced by changes in the $\left[\mathrm{NO}_{3}^{-}\right]:\left[\mathrm{PO}_{4}^{3-}\right]$ supply ratio will likely impact biogeochemistry during and after phytoplankton blooms as well as food-web dynamics. Biogeochemical responses to variations in nutrient supply and stoichiometry may differ between different pelagic communities, even in supposedly stable ecosystems such as the ETNA.

Acknowledgements. This research was supported by the Sonderforschungsbereich 754 "Climate-Biogeochemistry Interactions in the Tropical Ocean" (www.sfb754.de), subprojects B2 (J. Meyer), B8 (H. Hauss and R. Kiko) and B9 (A. Engel, C. Borchard, A. Loginova). The Sonderforschungsbereich 754 is supported by the German Science Foundation (DFG). The authors thank their colleagues from the INDP, Cape Verde, for their assistance with setting up the experiment and acknowledge the support of captain and crew of RV Islandia during initial sampling. We furthermore greatly acknowledge the technical support of Jon Roa (DOC, DON) and Ulrike Panknin (nutrients), as well as Nienke Bijma, Clarissa Karthäuser and Sami Manandhar (gel particle microscopy).

\section{Edited by: G. Herndl}

The article processing charges for this open-access publication were covered by a Research

Centre of the Helmholtz Association.

\section{References}

Agawin, N. S. R., Benavides, M., Busquets, A., Ferriol, P., Stal, L. J., and Aristegui, J.: Dominance of unicellular cyanobacteria in the diazotrophic community in the Atlantic Ocean, Limn. Oceanogr., 59, 623-663, 2014.

Alldredge, A. L., Passow, U., and Logan, B. E.: The abundance and significance of a class of large, transparent organic particles in the ocean, Deep-Sea Res., 40, 1131-1140, 1993.

Alldredge, A. L., Gotschalk, C., Passow, U., and Riebesell, U.: Mass aggregration of diatom blooms - Insights from a mesocosm study, Deep-Sea Res. Pt. II, 42, 9-27, 1995.

Aluwihare, L. I. and Repeta, D. J.: A comparison of the chemical characteristics of oceanic DOMand extracellular DOM produced by marine algae, Mar. Ecol.-Prog. Ser., 186, 105-117, 1999.

Arrigo, K. R.: Carbon cycle, Marine manipulations, Nature, 450, 491-492, 2007.

Azam, F., Fenchel, T., Field, J. G., Graf, J. S., Meyer-Rei, L. A., and Thingstad, F.: The ecological role of water- column microbes in the sea, Mar. Ecol.-Prog. Ser., 10, 257-263, 1983.
Baines, S. B. and Pace, M. L.: The production of dissolved organic matter by phytoplankton and its importance to bacteria: Patterns across marine and freshwater systems, Limnol. Oceanogr., 36, 1078-1090, 1991.

Baker, A. R., Weston, K., Kelly, S. D., Voss, M., Streu, P., and Cape, J. N.: Dry and wet deposition of nutrients from the tropical Atlantic atmosphere: links to primary productivity and nitrogen fixation, Deep-Sea Res. Pt. I, 54, 1704-1720, 2007.

Bar-Zeev, E., Berman-Frank, I., Stambler, N., Vázquez-Domínguez, E., Zohary, T., Capuzzo, E., Meeder, E., Suggett, D. J., Iluz, D., Dishon, G., and Berman, T.: Transparent exopolymer particles (TEP) link phytoplankton and bacterial production in the Gulf of Aqaba, Aquat. Microb. Ecol., 56, 217-225, doi:10.3354/ame01322, 2009.

Beauvais, S., Pedrotti, M. L., Villa, E., and Lemee, R.: Transparent exopolymer particle (TEP) dynamics in relation to trophic and hydrological conditions in the NW Mediterranean Sea, Mar. Ecol.-Prog. Ser., 262, 97-109, 2003.

Berman, T. and Viner-Mozzini, Y.: Abundance and characteristics of polysaccharide and proteinaceous particles in Lake Kinneret, Aquat. Micr. Ecol., 24, 255-264, 2001.

Biddanda, B. and Benner, R.: Carbon, nitrogen, and carbohydrate fluxes during the production of particulate and dissolved organic matter by marine phytoplankton, Limnol. Oceanogr., 42, 506518, 1997.

Bjørnsen, P. K.: Phytoplankton exudation of organic matter: Why do healthy cells do it?, Limnol. Oceanogr., 33, 151-154, 1988.

Borchard, C. and Engel, A.: Organic matter exudation by Emiliania huxleyi under simulated future ocean conditions, Biogeosciences, 9, 3405-3423, doi:10.5194/bg-9-3405-2012, 2012.

Borchard, C. and Engel, A.: Size-fractionated dissolved primary production and carbohydrate composition of the coccolithophore Emiliania huxleyi, Biogeosciences, 12, 1271-1284, doi:10.5194/bg-12-1271-2015, 2015.

Borchard, C., Borges, A., Händel, N. and Engel, A.: Biogeochemical response of Emiliania huxleyi (PML B92/11) to elevated $\mathrm{CO}_{2}$ and temperature under phosphorous limitation: a chemostat study, J.Exp. Mar. Biol. Ecol., 410, 61-71, 2011.

Chin, W. C., Orellana, M. V., and Verdugo, P.: Spontaneous assembly of marine dissolved organic matter into polymer gels, Nature, 391, 568-572, 1998.

Chow, J. S., Lee, C., and Engel, A.: The influence of extracellular polysaccharides, growth rate, and free coccoliths on the coagulation efficiency of Emiliania huxleyi, Mar. Chem., 175, 5-15, 2015.

Cisternas-Novoa, C., Lee, C., and Engel, A.: A semi-quantitative spectrophotometric, dye-binding assay for determination of Coomassie Blue stainable particles, Limnol. Oceanogr.Methods, 12, 604-616, 2014.

Cisternas-Novoa, C., Lee, C., and Engel, A.: Transparent exopolymer particles (TEP) and Coomassie stainable particles (CSP): Differences between their origin and vertical distributions in the ocean, Mar. Chem., 175, 56-71, 2015.

Claquin, P., Probert, I., Lefebvre, S., and Veron, B.: Effects of temperature on photosynthetic parameters and TEP production in eight species of marine microalgae, Aquat. Microb. Ecol. 51, 1$11,2008$. 
Codispoti, L. A. and Richards, F. A.: Analysis of horizontal regime of denitrification in Eastern Tropical North Pacific, Limn. Oceanogr., 21, 379-388, 1976.

Codispoti, L. A., Brandes, J. A., Christensen, J. P. , Devol, A. H., Naqvi, S. W. A., Paerl, H. W., and Yoshinari, T.: Scientia marina, The oceanic fixed nitrogen and nitrous oxide budgets: Moving targets as we enter the anthropocene?, 65, 85-105, 2001.

Corzo, A., Morillo, J. A., and Rodriguez, S.: Production of transparent exopolymer particles (TEP) in cultures of Chaetoceros calcitrans under nitrogen limitation, Aquat. Microb. Ecol., 23, 1, 63-72, 2000.

Del Giorgio, P. A. and Duarte, C.: Respiration in the open ocean, Nature, 420, 379-384, 2002.

Deutsch, C., Sarmiento, J. L., Sigman, D. M., Gruber, N., and Dunne, J. P.: Spatial coupling of nitrogen inputs and losses in the ocean, Nature, 445, 7124, 163-167, 2007.

Ducklow H. W., Purdie D. A., Williams P. J. L., and Davies J. M.: Bacterioplankton - a sink for carbon in a coastal marine plankton community, Science, 232, 865-867, 1986.

Engel, A.: Direct relationship between $\mathrm{CO}_{2}$ uptake and transparent exopolymer particles production in natural phytoplankton, $\mathrm{J}$. Plankton Res., 24, 49-53, 2002.

Engel, A.: Determination of Marine Gel Particles, Practical Guidelines for the Analysis of Seawater, CRC Press, 125-142, 2009.

Engel, A. and Passow, U.: Carbon and nitrogen content of transparent exopolymer particles (TEP) in relation to their Alcian Blue adsorption, Mar. Ecol.-Prog. Ser., 219, 1-10, 2001.

Engel, A., Goldthwait, S., Passow, U., and Alldredge, A.: Temporal decoupling of carbon and nitrogen dynamics in a mesocosm diatom bloom, Limnol. Oceanogr., 47, 753-76, 2002.

Engel, A., Thoms, S., Riebesell, U., Rochelle-Newall, E., and Zondervan, I.: Polysaccharide aggregation as a potential sink of marine dissolved organic carbon, Nature, 428 , 929-932, 2004a.

Engel, A., Delille, B., Jacquet, S., Riebesell, U., Rochelle-Newall, E., Terbrüggen, A., and Zondervan, I.: Transparent exopolymer particles and dissolved organic carbon production by Emiliania huxleyi exposed to different $\mathrm{CO}_{2}$ concentrations: a mesocosm experiment, Aquat. Microb. Ecol., 34, 93-104, 2004b.

Engel, A., Händel, N., Wohlers, J., Lunau, M., Grossart, H. P., Sommer, U., and Riebesell, U.: Effects of sea surface warming on the production and composition of dissolved organic matter during phytoplankton blooms: results from a mesocosm study, J. Plankton Res., 33, 357-372, 2011.

Engel, A., Piontek, J., Grossart, H. P., Riebesell, U., Schulz, K. G., and Sperling, M.: Impact of $\mathrm{CO}_{2}$ enrichment on organic matter dynamics during nutrient induced coastal phytoplankton blooms, J. Plankton Res., 36, 641-657, 2014.

Falkowski, P. G.: Rationalizing elemental ratios in unicellular algae, J. Phycol., 36, 3-6, 2000.

Fogg, G. E.: The ecological significance of extracellular products of phytoplankton photosynthesis, Bot. Mar., 26, 3-14, 1983.

Fraga, F.: Phytoplanktonic biomass synthesis: application to deviations from Redfield stoichiometry, Sci. Mar., 65, 153-169, 2001.

Franz, J. M. S., Hauss, H., Sommer, U., Dittmar, T., and Riebesell, U.: Production, partitioning and stoichiometry of organic matter under variable nutrient supply during mesocosm experiments in the tropical Pacific and Atlantic Ocean, Biogeosciences, 9, 46294643, doi:10.5194/bg-9-4629-2012, 2012a.
Franz, J., Krahmann, G., Lavik, G., Grasse, P., Dittmar, T., and Riebesell, U.: Dynamics and stoichiometry of nutrients and phytoplankton in waters influenced by the oxygen minimum zone in the eastern tropical Pacific, Deep-Sea Res. Pt. I, 62, 20-31, 2012 b.

Galgani, L., Stolle, C., Endres, S., Schulz, K. G., and Engel, A.: Effects of ocean acidification on the biogenic composition of the sea-surface microlayer: Results from a mesocosm study, J. Geophys. Res.-Oceans, 119, 7911-7924, doi:10.1002/2014JC010188, 2014.

Geider, R. J. and LaRoche, J.: Redfield revisited: variability of $\mathrm{C}: \mathrm{N}: \mathrm{P}$ in marine microalgae and its biochemical basis, Eur. J. Phycol., 37, 1-17, 2002.

Gilly, W. F. , Beman, J. M. , Litvin, S. Y. , and Robison, B. H.: Oceanographic and Biological Effects of Shoaling of the Oxygen Minimum Zone, Annu. Rev. Mar. Sci., 5, 393-420, 2013.

Goldman, J. C., McCarthy, J. J., and Peavey, D. G.: Growth rate influence on the chemical composition of phytoplankton in oceanic waters, Nature, 279, 210-215, 1979.

Grossart, H. P., Berman, T., Simon, M., and Pohlmann, K.: Occurrence and microbial dynamics of macroscopic organic aggregates (lake snow) in Lake Kinneret, Israel, in fall, Aquat. Microb. Ecol., 14, 59-67, 1998.

Grossart, H., Engel, A., Arnosti, C., De La Rocha, C. L., Murray, A. E., and Passow, U.: Microbial dynamics in autotrophic and heterotrophic seawater mesocosms, III. Organic matter fluxes, Aquat. Microb. Ecol. , 49, 143-156, 2007.

Hansell, D. A., Bates, N. R., and Olson, D. B.: Excess nitrate and nitrogen fixation in the North Atlantic Ocean, Mar. Chem., 84, 243-265, 2004.

Hansen, H. P. and Koroleff, F.: Determination of nutrients, edited by: Grasshoff, K., Kremling K., and Ehrhardt M., in: Methods of seawater analysis, 3rd ed. Wiley, 159-228, 2007.

Hauss, H., Franz, J. M. S., and Sommer U.: Changes in N : P stoichiometry influence taxonomic composition and nutritional quality of phytoplanton in the Peruvian Upwelling, J. Sea Res., 73, 74-85, doi:10.1016/j.seares.2012.06.010, 2012.

Hauss, H., Franz, J. M. S., Hansen, T., Struck, U., and Sommer U.: Relative inputs of upwelled and atmospheric nitrogen to the eastern tropical North Atlantic food web: Spatial distribution of $\delta^{15} \mathrm{~N}$ in meso zooplankton and relation to dissolved nutrient dynamics, Deep-Sea Res. Pt. I, 135-145, doi:10.1016/j.dsr.2013.01.010, 2013.

Karstensen, J., Fiedler, B., Schütte, F., Brandt, P., Körtzinger, A., Fischer, G., Zantopp, R., Hahn, J., Visbeck, M., and Wallace, D.: Open ocean dead zones in the tropical North Atlantic Ocean, Biogeosciences, 12, 2597-2605, doi:10.5194/bg-12-2597-2015, 2015.

Klausmeier, C. A., Litchman, E., Daufresne, T., and Levin, S. A.: Optimal nitrogen-to-phosphorus stoichiometry of phytoplankton, Nature, 429, 171-174, 2004.

Kreus, M., Schartau, M., Engel, A., Nausch, M. and Voss, M.: Variations in the elemental ratio of organic matter in the central Baltic Sea: Part I - Linking primary production to remineralization, Cont. Shelf Res., 100, 25-45, doi:10.1016/j.csr.2014.06.015, 2015.

Kuypers, M. M. M., Lavik, G., Woebken, D., Schmid, M., Fuchs, B. M., Amann, R., Jørgensen, B. B., and Jetten, M. S. M.: Massive nitrogen loss from the Benguela upwelling system through 
anaerobic ammonium oxidation, P. Natl. Acad. Sci. USA, 102, 6478-6483, doi:10.1073/pnas.0502088102, 2005.

Lam, P. and Kuypers, M. M. M: Microbial Nitrogen Cycling Processes in Oxygen Minimum Zones, Annu. Rev. Mar. Sci., 3, 31745, 2011.

Langlois, R. J., LaRoche, J., and Raab, P. A.: Diazotrophic Diversity and Distribution in the Tropical and Subtropical Atlantic Ocean, Appl. Environ. Microbiol., 71, 7910-7919, 2005.

Logan, B. E., Grossart, H.-P., and Simon, M.: Direct observation of phytoplankton, TEP and aggregates on polycarbonate filters using brightfield microscopy, J. Plankt. Res., 16, 1811-1815, 1994.

Long, R. A., and Azam, F.: Abundant protein-containing particles in the sea, Aquat. Microb. Ecol., 10, 213-221, 1996.

Mague, T. H., Friberg, E., Hughes, D. J., and Morris, I.: Extracellular release of carbon by marine phytoplankton; a physiological approach, Limnol. Oceanogr., 25, 262-279, 1980.

Mari, X. and Kiørboe T.: Abundance, size distribution and bacterial colonization of transparent exopolymeric particles (TEP) during spring in the Kattegat, J. Plankton Res., 18, 969-986, doi:10.1093/plankt/18.6.969, 1996.

Mari, X. and Robert, M.: Metal induced variations of TEP sticking properties in the southwestern lagoon of New Caledonia, Mar. Chem., 110, 98-108, 2008.

Mari, X.: Carbon content and $\mathrm{C}: \mathrm{N}$ ratio of transparent exopolymeric particles (TEP) produced by bubbling exudates of diatoms, Mar. Ecol.-Progr. Ser., 183, 59-71, 1999.

Meyer, J., Löscher, C. R., Neulinger, S. C., Reichel, A. F., Loginova, A., Borchard, C., Schmitz, R. A., Hauss, H., Kiko, R., and Riebesell, U.: Changing nutrient stoichiometry affects phytoplankton production, DOP build up and dinitrogen fixation a mesocosm experiment in the eastern tropical North Atlantic, Biogeosciences Discuss., 12, 9991-10029, doi:10.5194/bgd-129991-2015, 2015.

Mills, M. M. and Arrigo, K. R.: Magnitude of oceanic nitrogen fixation influenced by the nutrient uptake ratio of phytoplankton, Nat. Geosci., 3, 412-416, 2010.

Myklestad, S.: Production of carbohydrates by marine planktonic diatoms I, Comparison of nine different species in culture, J. Exp. Mar. Biol. Ecol., 15, 261-274, 1974.

Nagata, T.: Production mechanisms of dissolved matter, in: Microbial Ecology of the Oceans, edited by: Kirchmann, D. L., First edition, Wiley-Liss, New York, 121-152, 2000.

Olsen, Y., Agusti, S., Andersen, T., Duarte, C. M. , Gasol, J. M. , Gismervik, I. , Heiskanen, A-S., Hoell, E., Kuuppo, P. , Lignell, R., Reinertsen, H., Sommer, U., Stibor, H., Tamminen, T., Vadstein, O., Vaque, D., and Vidal, M.: A comparative study of responses in planktonic food web structure and function in contrasting European coastal waters exposed to experimental nutrient addition, Limn. Oceanogr., 51, 488-503, 2006.

Pantoja, S., Sepulveda, J. S., and Gonzalez, H. E.: Decomposition of sinking proteinaceous material during fall in the oxygen minimum zone off northern Chile, Deep-Sea Res. Pt. I, 51, 55-70, doi:10.1016/j.dsr.2003.09.005, 2004.

Pantoja, S., Rossel, P., Castro, R., Cuevas, L. A., Daneri, G., and Cordova, C.: Microbial degradation rates of small peptides and amino acids in the oxygen minimum zone of Chilean coastal waters, Deep-Sea Res. Pt. II, 56, 1019-1026, doi:10.1016/j.dsr2.2008.09.007, 2009.
Parsons, T. R., Maita, Y., and Lalli, C. M.: A manual of chemical and biological methods for seawater analysis Pergamon Press Oxford, UK, 173 pp., 1984.

Passow, U.: Transparent exopolymer particles (TEP) in aquatic environments, Prog. Oceanogr., 55, 287-333, 2002.

Passow, U., Shipe, R. F., Murray, A., Pak, D. K., Brzezinski, M. A., and Alldredge, A. L.: The origin of transparent exopolymer particles (TEP) and their role in the sedimentation of particulate matter, Cont. Shelf Res., 21, 327-346, 2001.

Pedrotti, M. L., Peters, F., Beauvais, S., Vidal, M., Egge, J., Jacobsen, A., and Marrase, C.: Effects of nutrients and turbulence on the production of transparent exopolymer particles: a mesocosm study, Mar. Ecol.-Prog. Ser., 419, 57-69, 2010.

Prieto, L., Ruiz, J., Echevarrìa, F., Garcìa, C. M., Bartual, A., Gálvez, J. A., Corzo, A., and D. Macìas: Scales and processes in the aggregation of diatom blooms: high time resolution and wide size range records in a mesocosm study, Deep-Sea Res. Pt. I, 49, 1233-1253, 2002.

Radic, T., Ivancic, I., Fuks, D., and Radic, J.: Marine bacterioplankton production of polysaccharidic and proteinaceous particles under different nutrient regimes, FEMS Microb. Ecol., 58, 333342, 2006.

Rahav, E., Bar-Zeev, E., Ohayon, S., Elifantz, H., Belkin, N., Herut, B., Mulholland, M. R., and Berman-Frank, I.: Dinitrogen fixation in aphotic oxygenated marine environments, Front. Mar. Microbiol., 4, 1-11, 2013.

Redfield, A. C.: The biological control of chemical factors in the environment, Am. Sci., 46, 205-221, 1958.

Redfield, A. C., Ketchum, B. H., and Richards, F. A.: The influence of organisms on the composition of seawater, in: The sea, ideas and observations on progress in the study of the seas, Vol 2, edited by: Hill, M. N., Interscience, 26-77, 1963.

Rhee, G. Y.: Effect of $\mathrm{N}: \mathrm{P}$ atomic ratios and nitrate limitation on algal growth, cell composition, and nitrate uptake, Limnol. Oceanogr., 23, 10-25, 1978.

Sarmiento, H. and Gruber, N. L.: Ocean Biogeochemical Dynamics, Princeton University Press, 186-200, 2006.

Schartau, M., Engel, A., Schröter, J., Thoms, S., Völker, C., and Wolf-Gladrow, D.: Modelling carbon overconsumption and the formation of extracellular particulate organic carbon, Biogeosciences, 4, 433-454, doi:10.5194/bg-4-433-2007, 2007.

Schneider, B., Engel, A., and Schlitzer, R.: Effects of depth- and $\mathrm{CO}_{2}$-dependent $\mathrm{C}: \mathrm{N}$ ratios of particulate organic matter (POM) on the marine carbon cycle, Global Biogeochem. Cy., 18, 1-13, doi:10.1029/2003GB002184, 2004.

Sharp, J. H.: Improved analysis for particulate organic carbon and nitrogen from seawater, Limnol. Oceanogr., 19, 984-989, 1974.

Sharp, J. H.: Excretion of organic matter by marine phytoplankton - Do healthy cells do it?, Limnol. Oceanogr., 22, 381-399, 1977.

Sommer, U., Hansen, T., Stibor, H., and Vadstein, O.: Persistence of phytoplankton responses to different $\mathrm{Si}: \mathrm{N}$ ratios under mesozooplankton grazing pressure: a mesocosm study with NE Atlantic plankton, Mar. Ecol.-Prog. Ser., 278, 67-75, 2004.

Sterner, R. W. and Elser, J. J.: Ecological Stoichiometry: The Biology of Elements from Molecules to the Biosphere, ISBN: 9780691074917, 464 pp., 2002.

Stramma, L., Johnson, G. C., Sprintall, J., and Mohrholz, V.: Expanding Oxygen-Minimum Zones in the Tropical Oceans, Science, 320, 655-658, doi:10.1126/science.1153847, 2008. 
Sugimura, Y. and Suzuki, Y.: A high-temperature catalytic oxidation method for the determination of non-volatile dissolved organic carbon in seawater by direct injection of a liquid sample, Mar. Chem., 24, 105-131, 1988.

Thingstad, T. F., Hagstrom, A., and Rassoulzadegan, F.: Accumulation of degradable DOC in surface waters: Is it caused by a malfunctioning microbial loop?, Limnol. Oceanogr., 42, 398-404, 1997.

Thornton, D. C. O.: Effect of low $\mathrm{pH}$ on carbohydrate production by a marine planktonic diatom (Chaetoceros muelleri), Res. Lett. Ecol., 105901, doi:10.1155/2009/105901, 2009.

Toggweiler, J. R.: Carbon overconsumption, Nature, 363, 210-211, 1993.
Vadstein, O., Andersen, T., Reinertsen, H. R., and Olsen, Y.: Carbon, nitrogen and phosphorus resource supply and utilisation for coastal planktonic heterotrophic bacteria in a gradient of nutrient loading, Mar. Ecol.-Prog. Ser., 447, 55-75, 2012.

Verdugo, P., Alldredge, A. L., Azam, F., Kirchman, D. L., Passow, U., and Santschi, P. H.: The oceanic gel phase: a bridge in the DOM-POM continuum, Mar. Chem., 92, 67-85, 2004.

Wood, M. A. and van Valen, L. M.: Paradox lost? On the release of energy-rich compounds by phytoplankton, Mar. Microb. Food Webs 4, 103-116, 1990.

Wurl, O., Miller, L., and Vagle, S. Production and fate of transparent exopolymer particles in the ocean, J. Geophys. Res., 116 , C00H13, doi:10.1029/2011JC007342, 2011. 